\title{
BIM in the Center of Digital Transformation of the Construction Sector-The Status of BIM Adoption in North Macedonia ${ }^{\dagger}$
}

\author{
Lihnida Stojanovska-Georgievska ${ }^{1, *(\mathbb{D})}$, Ivana Sandeva ${ }^{1}\left(\mathbb{D}\right.$, Aleksandar Krleski ${ }^{1}$, Hristina Spasevska ${ }^{1}{ }^{(\mathbb{C}}$, \\ Margarita Ginovska ${ }^{1}{ }^{\circledR}$, Igor Panchevski ${ }^{1,2}$, Risto Ivanov ${ }^{2}$, Ignasi Perez Arnal ${ }^{3}$, Tomo Cerovsek ${ }^{4}$ \\ and Tomas Funtik ${ }^{5}$
}

\section{check for}

updates

Citation: Stojanovska-Georgievska,

L.; Sandeva, I.; Krleski, A.; Spasevska,

H.; Ginovska, M.; Panchevski, I.;

Ivanov, R.; Perez Arnal, I.; Cerovsek,

T.; Funtik, T. BIM in the Center of

Digital Transformation of the

Construction Sector-The Status of BIM Adoption in North Macedonia Buildings 2022, 12, 218. https:/ / doi.org/10.3390/buildings12020218

Academic Editor: Bo Xia

Received: 24 December 2021

Accepted: 9 February 2022

Published: 15 February 2022

Publisher's Note: MDPI stays neutral with regard to jurisdictional claims in published maps and institutional affiliations.

Copyright: (C) 2022 by the authors. Licensee MDPI, Basel, Switzerland. This article is an open access article distributed under the terms and conditions of the Creative Commons Attribution (CC BY) license (https:// creativecommons.org/licenses/by/ $4.0 /$ )
1 Faculty of Electrical Engineering and Information Technologies, Ss Cyril and Methodius University, Rugjer Boskovic 18, 1000 Skopje, North Macedonia; ivana@feit.ukim.edu.mk (I.S.); krleski@feit.ukim.edu.mk (A.K.); hristina@feit.ukim.edu.mk (H.S.); gmarga@feit.ukim.edu.mk (M.G.); igor@kreacija.org (I.P.)

2 Kreacija Association of Business and Consultants Skopje, Nikola Parapunov 41, 1000 Skopje, North Macedonia; risto@kreacija.org

3 BIM Academy, WITS Institute SL, Calle de Mallorca 346, 08013 Barcelona, Spain; ignasiperezarnal@bimacademy.es

4 Faculty of Civil and Geodetic Engineering, University of Ljubljana, Kongresni trg 12, 1000 Ljubljana, Slovenia; tomo.cerovsek@fgg.uni-lj.si

5 Faculty of Civil Engineering, Slovak University of Technology in Bratislava, Radlinského 11, 81005 Bratislava, Slovakia; tomas.funtik@stuba.sk

* Correspondence: lihnida@feit.ukim.edu.mk; Tel.: +389-71-39-77-80

$+\quad$ This paper is an extended version of our paper published in the 9th Annual Edition of Sustainable Places (SP 2021) Conference, Rome, Italy, 29 September 2021; p. 8.

\begin{abstract}
The building sector nowadays has come to the stage where it needs a "digital" renovation This is to be accomplished by an introduction of change into the methodology of construction and using new tools and technologies, such as BIM technology. This paper gives an insight into the status of BIM adoption in North Macedonia. It presents the threefold actions toward introduction of BIM in the national construction industry. These actions refer to scanning the current situation regarding digitalization of the sector, then taking promotional actions to express the benefits of BIM, and finally identifying and proposing the most suitable measures, summarized in the proposal of the National Roadmap for BIM adoption. The methods used consist of a brief literature review of the global status of BIM development. Then, the results of a survey conducted on more than 300 respondents representing a sample of building professionals in the country are discussed, and the barriers for successful BIM adoption are accordingly identified. The next step is to showcase the potential benefits of BIM for assessment of energy performance of buildings. As a final point, the conclusions drafted toward identification of the most important challenges are addressed in the proposed National Roadmap for BIM adoption.
\end{abstract}

Keywords: digitalization; BIM; construction; productivity; energy performance; BIM roadmap

\section{Introduction}

Construction serves as an integral part of the economy worldwide. About $6 \%$ of global GDP is generated by engineering and construction (E\&C) activities, or approximately $\$ 10$ trillion in the annual revenue. However, if we consider the level of productivity, the industry is failing to keep up with the gains made by other industries [1]. This disables wider growth of national economies, especially ones that rely more on construction, which is the case in North Macedonia. This industry has a very low level of adoption of new technologies, thus resulting in lower project efficiencies and a lower labor productivity. Digitalization has the potential to change this situation. The construction industry has continued to operate as in the past 50 years and remains the least digitized sector (except 
for agriculture) [2,3]. In this sector, manual labor is still mostly "on-board", together with commonly having workers with the type of knowledge based on "all-in-one" experience, without an insight into new technologies and established operating and business models, as is commonly the case in the Macedonian construction sector [4].

Embracing digitalization is necessary in order to increase the productivity of the sector and to bring innovations into the service of infrastructure and urban development (IU). Building information modeling (BIM) is a key first step toward these goals $[5,6]$. Concepts such as an increased productivity and efficiency, sustainability, an increased security, or saving financial resources are becoming synonymous with digitalization, but, over the last 20 years, productivity gains have only been about $1 \%$. The implementation of BIM in construction is evidently a clear act toward digitalization, and it is expected that it will bring $13-21 \%$ savings in the design and implementation phase and $10-17 \%$ in the operation and maintenance within the global infrastructure market by 2025 [7-9].

BIM is the central piece of the industry's digital transformation based on a collaboration between different professional groups. It powers new technologies, such as mobile applications, automatization of processes, remotely driven equipment, and prefabrication, that are some of the "must-have" technologies when we speak about BIM. BIM is often perceived as a software for simulation of physical but also functional assets of an object, thus enabling new services and use of digital technologies [10-13].

\subsection{Global Status of BIM Adoption}

BIM as a new technology started its introduction in the construction sector over the last two decades, and it offers tools for transformation and enhancement of project performance and productivity by decreasing inefficiencies and lowering non-productivity, as well as by increasing the collaboration among different groups of project stakeholders. However, a number of barriers and obstacles have inhibited its more extensive implementation, despite the potential benefits [14]. BIM adoption means "the successful implementation whereby an organization, following a readiness phase, crosses the 'Point of Adoption' into one of the BIM capability stages, namely, modeling, collaboration, and integration". Over the past years, the adoption of BIM has significantly increased worldwide and particularly in the highly developed countries [15].

The United States are one of the pioneers in BIM development, whose adoption in the construction industry started from 2003 by launching the "National 3D-4D program" for gradual implementation of 3D, 4D, and BIM for all major public projects.

The first European legislative incentives toward BIM were released in 2014 with the European Commission directive 2014/24/EU, which recommended to member states "to use specific electronic tools such as BIM for public work contracts and design contests" (European Parliament, 2014). The UK is widely perceived to be a global leader in the adoption of BIM technology. After requiring BIM in all public works by 2016, the UK has moved toward BIM level 3, resulting in almost $70 \%$ of all professionals in the British construction industry using BIM by 2019 [16,17]. The Scandinavian countries are at the forefront of BIM adoption. In 2011, in the Netherlands, the Government Buildings Agency mandated the use of BIM for all public projects. Wide adoption of BIM is also shown in other EU countries, such as France, Germany, and Austria.

The situation with the introduction of BIM has changed in a more positive direction with the putting into place of BIM standards as European standards. In parallel, on the local level, there are national standards that are sometimes different from the standards at the European level in order to better reflect the national conditions [18-20].

The Republic of North Macedonia, as a part of the global community, is following the directions of the global movement toward digitalization in all sectors. However, the country is still in the very first segment of the road to more significant implementation of BIM. Therefore, the need to investigate the current status of BIM on the national level, to probe the attitude and preparedness of the sector toward its introduction, as well as to identify the main obstacles for wider BIM adoption on the national level arise as a necessary 
topic for profound exploration and study. A supporting consideration for justification of this need is the fact that also the literature review has identified a gap regarding sources related to the status or implementation of BIM at the national level. In fact, there are almost no publications and relevant sources in this topic, except for the references to the actions undertaken in the frame of the H2020 project TRAINEE, whose results will be a subject of elaboration in this work.

\subsection{Benefits and Barriers for BIM Adoption}

The literature review identifies many reported advantages of BIM adoption for executing construction projects over the traditional construction practices [21-24]. BIM benefits are identified in different building life cycle phases, as briefly summarized in Table 1.

Table 1. Benefits of BIM adoption.

\begin{tabular}{|c|c|c|c|}
\hline Phases & Pre-Construction & Construction & Post-Construction \\
\hline 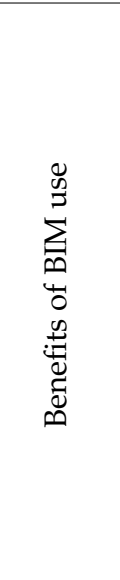 & $\begin{array}{l}\text { Introduction of GIS (geographic } \\
\text { information systems) data in } \\
\text { digital infrastructure models } \\
\text { Improved accuracy of the data by } \\
\text { using point cloud data of the site } \\
\text { - Improving applicability of energy } \\
\text { efficiency measures } \\
\text { - } \\
\text { Reducing design clashes in the } \\
\text { early stage by visual } \\
\text { representation of the model } \\
\text { Enhancing the accuracy of } \\
\text { cost estimation } \\
\text { Checking of project } \\
\text { constructability and sustainability }\end{array}$ & 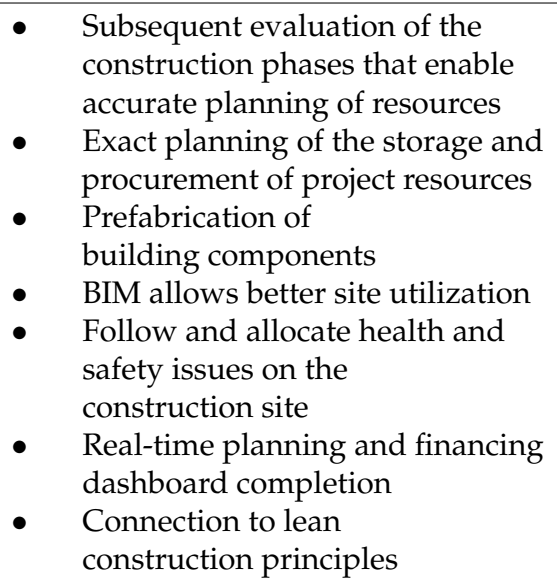 & $\begin{array}{l}\text { BIM as-built model after the } \\
\text { construction effectively } \\
\text { supports the operations, } \\
\text { maintenance, repair, and } \\
\text { replacement of appliances } \\
\text { Supports accurate and } \\
\text { in-time management of } \\
\text { the assets } \\
\text { Enables exact scheduling of } \\
\text { maintenance operations and } \\
\text { easy access to information } \\
\text { Preview of disassembling } \\
\text { process for the end of the } \\
\text { use of the facility }\end{array}$ \\
\hline
\end{tabular}

The literature review reports show that the barriers to BIM adoption are common for both developed and developing countries [25-27]. Table 2 summarizes some of the most frequently identified barriers for BIM adoption in the construction industry.

Table 2. Barriers for BIM adoption.

\begin{tabular}{|c|c|c|}
\hline Origin & Personal & Corporate \\
\hline 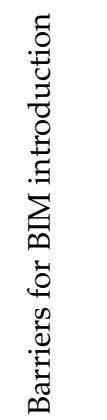 & $\begin{array}{l}\text { - } \quad \text { Lack of awareness regarding the potential of BIM } \\
\text { - } \quad \text { Low and inadequate offer of BIM trainings } \\
\text { - } \quad \text { mo support from company's } \\
\text { - } \quad \text { Longer time for model developing } \\
\text { - } \quad \text { Problem with software programs' interoperability } \\
\text { - } \quad \text { Nonexistent standardized tools and procedures }\end{array}$ & 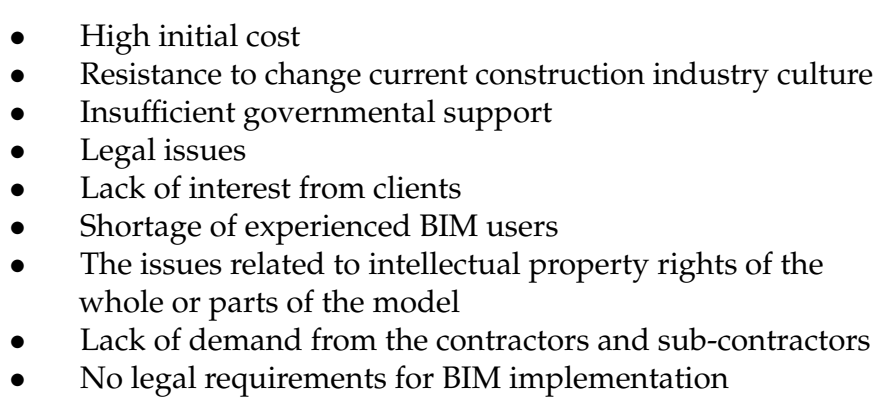 \\
\hline
\end{tabular}

The brief scope into the global state of the art given above aims to give a general scope of the level of development reached by developed countries in order to identify the degree of lagging behind of the Macedonian construction sector and, even more importantly, to identify the good practice examples to follow in a proposed national approach. This also applies to the summarized information in Tables 1 and 2, which result from the summary of the most commonly identified benefits and barriers for BIM adoption worldwide. This 
extraction of the most frequently cited literature data will serve as a reference point to compare the identified issues from the corresponding categories after investigating the situation on the national level further in the study.

\subsection{Key Insights and Recommended Actions for BIM Introduction}

The World Economic Forum (WEF) report from 2016 notifies that the construction sector is evidently lagging behind most other industries in terms of embracing digital technologies. Other sectors have undergone tremendous changes during the last few decades and have experienced the benefits of the use of new processes and product innovations [5].

The increased efficiencies tackled with this change are becoming more and more recognized by governments across the globe [28,29]. Governments are learning from the good practice examples that strategic support of lean construction, BIM, and other innovations in the sector can help to address the rising problem with productivity in construction.

Increasing BIM adoption requires greater collaboration between different professional groups, higher motivation of the stakeholders, and expressing the right professional capabilities (Figure 1). In this process, the stakeholders from the construction industry should have the crucial role, but the first step is to understand how BIM benefits them and adds value to their projects. This should further develop new collaboration forms and should result in increased teamwork, integration of contracting processes, and implementation standards for sharing the project data among all of the relevant parties involved [30-32].

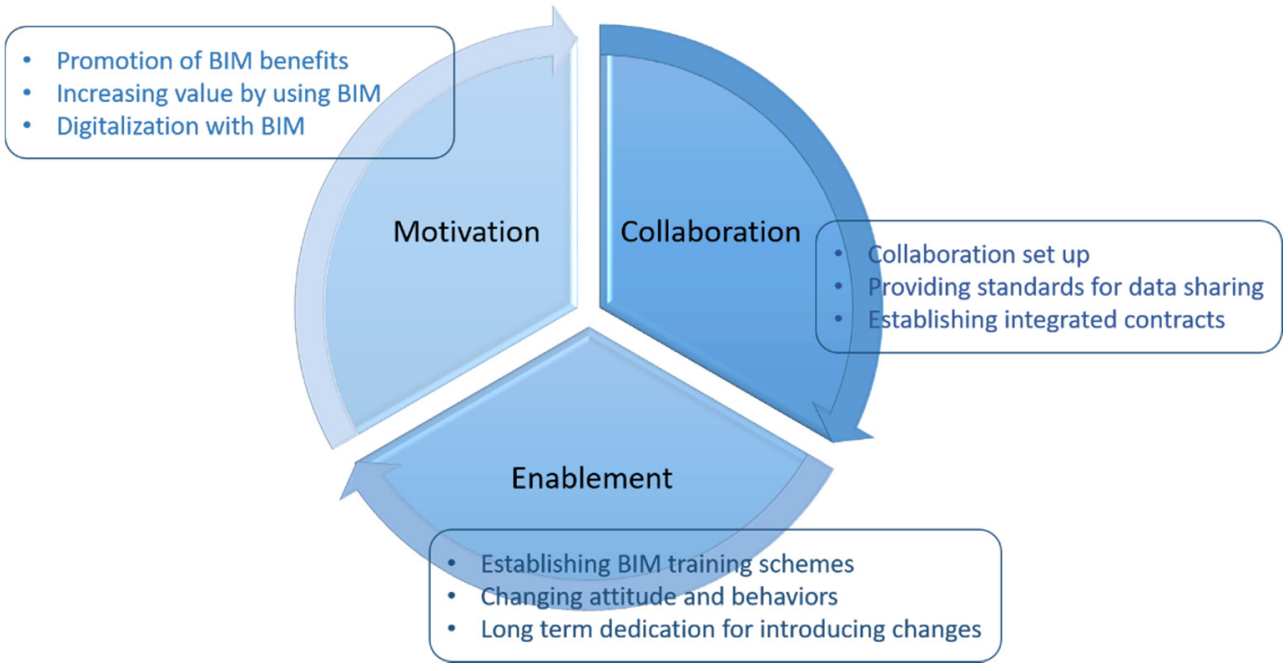

Figure 1. Fields of action toward BIM adoption (adopted by WEF), adapted from Ref. [6].

The approach proposed by WEF toward initiating adoption of digital transition is reflected in most of the countries that can evaluate their stage of BIM development as a successful one. It consists of a three-step organization of the target actions:

- Motivation

- Collaboration

- Enablement

\section{Objectives and Aim of the Paper}

The brief scope into the global status of BIM implementation given above does not aim to give a precise overview of the worldwide situation but rather to shed light on the level of development reached by developed countries in order to identify the degree of lagging behind of the Macedonian construction sector and to follow these achievements as targets in creating proposal and selecting measures to be undertaken on the national level further in the study. The previous paragraph reports on different levels of penetration of BIM in different countries, depending on the peculiarities of the national conditions, 
mainly in terms of the legal enablement and the procurement requirements, but they all have in common the unwavering determination to introduce digitalization into the national building sectors.

The Republic of North Macedonia, as a candidate country for EU membership, follows and transposes European legislation, including that regarding the use of digital tools in construction. However, the country is still at the start of enabling more significant implementation of BIM.

The current status of BIM, on a national level, regarding professionals' perception of it has not been studied elsewhere yet. This also applies to identification of the main obstacles and barriers for wider BIM adoption on a national level. These targets are the initial objectives of the research work presented in this paper. This paper, nonetheless, goes much further than just giving an insight into the attitude and awareness about BIM. Especially for a country with no particular advances in this topic such as North Macedonia, we find it necessary as well to consider a broader scope of actions to tackle the need for digital changes, to present some actions toward their enablement, and to propose measures and steps for a successful change in this situation.

In the following subsections, we will refer to the most commonly identified benefits and barriers for BIM adoption on a global level, including the successful actions taken to enable BIM implementation by other countries, identified through a literature review, in order to better explain the whole scope and background of the proposed actions. This will also serve for comparing these actions with the ones determined as appropriate on a national level. In addition, by referring to them, the selection of the most adequate measures will be governed so as to define an organized and structured approach to bring the national construction industry in track with contemporary achievements.

\section{Specific Aim and Approach of the Study}

The main objective of the paper has a broad scope-to give an extensive insight into the status of BIM adoption in North Macedonia and to propose a set of threefold actions toward introduction of BIM in the national construction industry. These threefold actions apply to an array of steps and organized efforts toward an introduction of BIM on the national level. Starting with scanning the current situation regarding digitalization of the sector, then taking promotional actions to express the benefits of BIM, and finally by identifying and proposing the most suitable measures, summarized in the proposal of the National Roadmap for BIM adoption, these actions are organized according to the three-step approach proposed by WEF, related to motivation, collaboration, and enablement.

In order to explain the starting points and the desired outcome of the whole process of initiating BIM, we propose this threefold approach, which can be expressed in terms of the process loop consisting of the three specific aims of this paper (Figure 2).

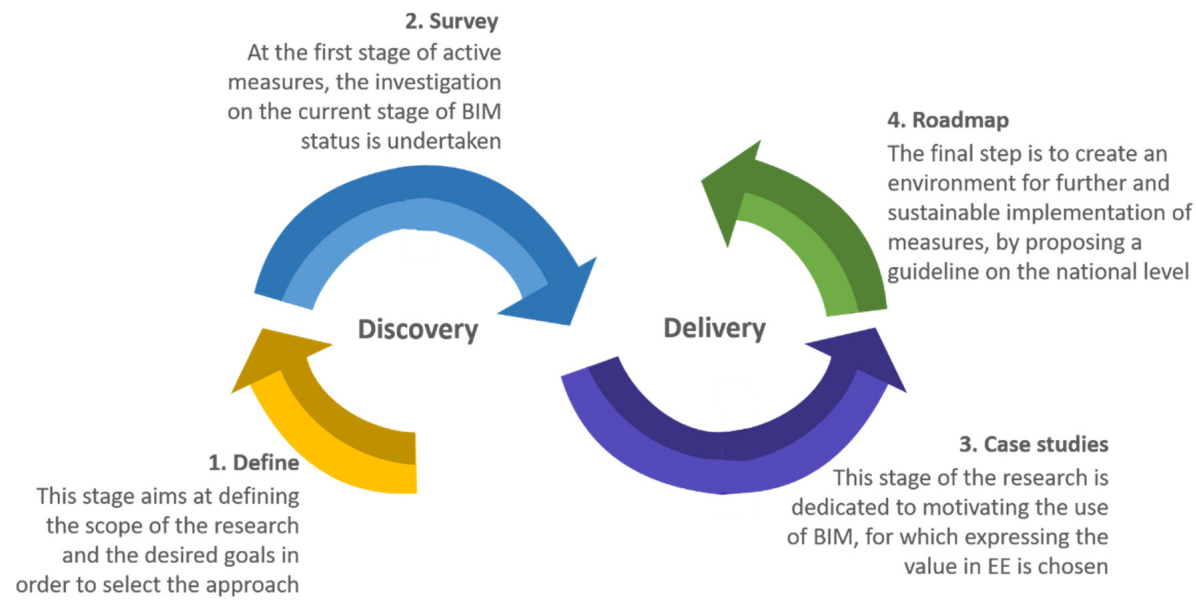

Figure 2. Specific aims of the paper presented as successive steps in a process loop. 
After defining the scope of the paper and its impact, the three main consecutive actions are presented. These actions are consequently aligned, each dependent on the previous one. These three specific aims of the paper are aligned as successive steps, to lead to the desired goal and the enablement of more intense adoption of BIM. These specific aims are defined as:

1. Investigating the level of BIM awareness among building professionals in the Republic of North Macedonia-the method used is conducting a survey, as described in Section 3.1, while the survey results are analyzed in Section 4.1.

2. Demonstrating the feasibility of BIM adoption for energy consumption purposes-the method used is conducting case studies on the benefit of BIM for improving the energy performance of buildings, which is explained in Section 3.2, and the results of the case studies are then discussed in Section 4.2 of the paper.

3. Tracing the path for further BIM introduction in the construction sector-by proposing a document roadmap for national BIM adoption, whose approach is explained in Section 3.3, while the proposal itself is elaborated in Section 4.3.

Further in the paper, the following sections will explain the implemented methods in more detail, followed by the discussion and analysis of the obtained results.

\section{Materials and Methods}

Introducing digitalization in the construction sector in the Republic of North Macedonia is still at the beginner's level. Moreover, the experience of rare professionals and the sporadic implementation by a very few small design studios are a matter of ambitious devotion of the rare exceptions among construction engineers and architects who had embraced self-learning, aiming for further professional development. The remaining majority of the sector is still strongly traditional, both on an operational and management level. Thus, the initiatives for settling BIM implementation are easy to notice. Most of these initiatives are project-driven. Among them, one of the widest actions for the introduction of BIM was implemented by the H2020 project TRAINEE, https: / / trainee-mk.eu/en/ (accessed on 8 February 2022). The project TRAINEE (Toward market-based skills for sustainable energy-efficient construction) is built on the results of the previous national actions in the Build Up Skills Initiative in Pillars 1 and 2, concerning two priorities: creating a skilled building workforce and overcoming the barriers to implementation of EE measures in construction, operation, and maintenance. The overall objective of TRAINEE was to increase the number of skilled building professionals by addressing three topics:

(a) upgrading and developing qualifications and training schemes and setting up largescale qualification for on-site workers, installers, and building professionals for energy efficiency measures in construction and renewable energy;

(b) improving the multidisciplinary approach to sustainable construction by initiating BIM at the national level as a tool to demonstrate reduction of the energy performance gap and for measurable energy saving resulting from improved construction skills; and

(c) market acceptance of developed construction skills by construction companies and professional trade associations through focusing on the higher value of the buildings, improved appreciation of the end user's satisfaction and quality of living, as well as increased market value of the companies that employ skilled professionals.

Having initialization of BIM as one of its main objectives, this project has taken the leading role to bring BIM technology closer to professionals in a wide range, thus acting as a promoter of digitalization in construction on the national level. Threefold actions were implemented: wide promotional activities and introductory campaign; development of training programs and training content and piloting the training schemes; and eventual drafting of the proposal for a national document to act as a guidebook for national BIM implementation. Thus, TRAINEE has been marked as a narrator of the new coming digital era in national construction. 
The threefold actions discussed in this paper are undertaken in the frame of the TRAINEE project. They apply to the specific aims of the paper: to conduct a survey in order to study the level of BIM awareness; then, an exercise to demonstrate the value of BIM through expressing BIM benefits in achievement of energy efficiency; and, as an ultimate goal, to propose a detailed plan for the necessary actions to enable national BIM introduction.

\subsection{BIM Survey for Level of Awareness}

In order to weigh the penetration and acceptance of BIM practice in North Macedonia, a survey on the level of awareness, knowledge, and experience in implementing BIM practice was carried out within the project TRAINEE involving professionals from the Macedonian construction sector $[33,34]$.

\subsubsection{Selection of the Method and Survey Sample}

According to the implemented methodology, as a technique for gathering data, a survey method was chosen consisting of questions distributed to different professional groups. The questionnaires were distributed via electronic communication by using the Google survey tool.

The respondents were selected by inviting them to participate in the survey, using the mailing lists of the registered professionals in the official Chamber of Certified Architects and Certified Engineers of Republic of North Macedonia and then the mailing lists of the members of other professional associations in the sector, such as the Engineering Institution of Macedonia; then, the companies working in the construction and energy sectors were invited to participate in the survey through the communication channels of the Economic Chamber of North Macedonia, and, finally, the representatives from the authorities and the public sector were reached using the communication network of the steering committee of the project.

An e-mail reminder was sent twice during the one-month period during which the survey was conducted.

Since building information modeling (BIM) aims to induce changes in both public and private sectors to work together in design, solving problems, and building better projects, faster and at less cost, the respondents involved in the survey were from three main sectors: AEC, public authorities, and academia. There were 1500 questionnaires distributed by e-mail among state officials, construction companies, and building professionals with job experience in AEC (architecture, engineering, and construction). From the total of 57,000 employees in the national construction sector, the sample size of 1500 questionnaires makes a $2.6 \%$ sample size percentage relative to the total population of interest. There were 312 valid responses obtained, which represents a 20,8\% respondent answer rate. Responses were analyzed by using simple qualitative analysis of the obtained results because of the rather low answering rate relative to the total number of the sample size. Most of the total 312 respondents belonged to the AEC (architecture, engineering, and construction) sector, with over $78 \%$ share, or 244 respondents, while the public sector was represented with 55 respondents, or $18 \%$ share in the total number of valid responses, and academia was represented with 13 respondents, or $4 \%$. The detailed structure of the companies to which the respondents belong is given in Table 3. 
Table 3. Statistics about the profiles of the companies to which the respondents belong.

\begin{tabular}{|c|c|c|c|c|c|c|c|}
\hline \multirow{3}{*}{$\frac{\text { Number of Companies }}{\text { Sector }}$} & \multicolumn{6}{|c|}{ Company Profile } & \\
\hline & \multirow{2}{*}{\multicolumn{2}{|c|}{$\begin{array}{l}\text { Building sector } \\
230\end{array}$}} & & \multirow{2}{*}{\multicolumn{2}{|c|}{$\begin{array}{l}\text { Infrastructure } \\
82\end{array}$}} & & \\
\hline & & & & & & & \\
\hline \multirow[t]{2}{*}{ Size of the company } & $1-4$ & $5-10$ & $11-20$ & $21-49$ & $50-99$ & over 100 & \\
\hline & 91 & 48 & 33 & 41 & 18 & 81 & \\
\hline \multirow[t]{2}{*}{ Field } & Construction & Investment & Public sector & Control & Design & University & Management \\
\hline & 60 & 6 & 18 & 31 & 177 & 13 & 7 \\
\hline
\end{tabular}

\subsubsection{Preparation of Survey Questions and Structuring the Questionnaire}

The exact formulation of the questions is presented in the graphical representation describing the survey's logic jumps, given in Figure 3 below.

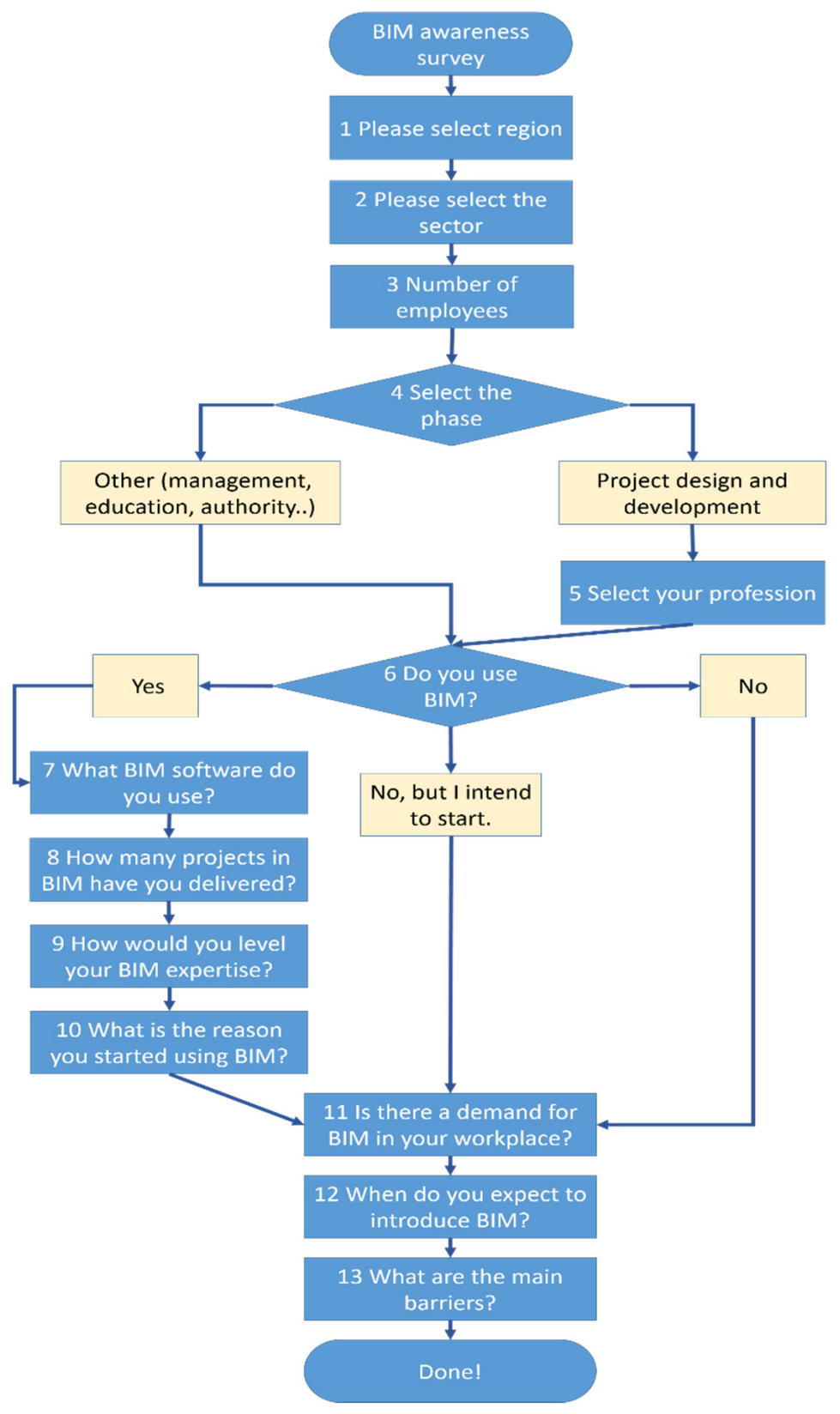

Figure 3. BIM awareness survey logic jumps. 
The questions were close-end, and the questionnaire contained two parts.

- Part 1 included questions about respondents' geographical location, field of work in the construction sector, number of employees, current career stage (architect or engineer);

- $\quad$ Part 2 included questions about the skills of respondents in drawing, CAD tools, BIM, and use of software. This part also included the identified barriers for BIM implementation.

Questions from part 2 were precisely addressed with survey logic jumps, depending on the answers to the selection-making questions, that were used to determine the next questions in the survey (Figure 3).

\subsection{Expresing the Value of BIM in Achieving Energy Efficiency in Construction}

The second action undertaken in this work was realized in order to provoke stronger BIM penetration in practice, through a wide and comprehensive promotional action. Furthermore, to trigger more intense BIM implementation on the national level or introduction of BIM topics in academia and professional associations, the demonstration of the best practices and successful case studies appears to be the most indisputable approach for expressing the benefits. As explained above, in order to overcome the identified barriers that hamper BIM implementation on a national level, a set of measures were implemented by the H2020 project TRAINEE:

- $\quad$ wide public promotion of BIM involving six promotional workshops that gathered more than 300 interested building professionals and other stakeholders involved in the whole life cycle of construction [33];

- development of four qualification schemes for BIM for which series of pilot trainings were organized in order to make BIM benefits more understandable to the industry and the technicians involved;

- drafting a document that pathways the step-by-step introduction of BIM in a national construction industry. This document is the first of its kind in the country submitted for approval by the relevant authorities and aiming to support the implementation of the new national legislation for public procurement that should introduce the requirements for use of electronic tools in the procurement procedures, as encouraged by the Directive 2014/24/EU.

However, the strongest promotional impact comes from the demonstration of benefits of using BIM tools, as the certified professionals for BIM, through the pilot trainings, were engaged in piloting the use of a BIM software in order to express the potential of BIM for reduction of two gaps:

1. the first one between the projected and the actual energy consumption in the phase after construction, which can be reduced with better design of new buildings regarding their orientation and materials and minimizing energy needs; and

2. the second one between designed and actual energy performance of the building [33-36].

The first gap was demonstrated with a comparison of architectural design and the asbuilt object through analysis of construction materials used, the chosen products, systems installed, and energy efficiency solutions executed, which have made the difference between building qualities visible for both construction companies and consumers.

The second gap was demonstrated with a comparison between performance indicators during architectural design and the actual energy consumption after several years of usage.

\section{Building Energy Modeling-BEM}

Executing energy performance simulation of a building is a challenging task, especially as the building design usually experiences changes during the construction phase and dynamic changes in real time while it is being used. A building design process includes a series of activities and decisions in each design phase, but real occupancy, natural behaviors of its occupants, final thickness of used insulation materials, the accessibility to control devices, etc. make uncertain the complete accountability of the final energy state, even though it is made by professionals. In general, there are three phases of a new building 
project: concept or pre-design, final concept design, and development of executive detailed design and construction model. Thus, the modeling of building energy through BIM (in this case, known as building energy modeling-BEM) can be outdated if it is not fully connected with a building data model. This means that BIM and BEM procedures are to be executed simultaneously or, even better, in an integrated manner. Embedding the joint $\mathrm{BIM}+\mathrm{BEM}$ process is a solution offering multiple iterations toward an optimized design in the environment of shared building data [35]. The difficulty in finding proper examples, investigation, and also specialized software and hardware demonstrates the value of the TRAINEE program.

There are three different methods for integrating BIM and BEM procedures [37,38]:

- Combined method: achieved by combining the BIM model and BEM sub-model, where both are completed using one or more tools. This requires a multi-specialized professional proficient in engineering and also in architectural tasks to complete the modeling and simulating in real time. The available software market does not provide a unique software that helps with that process, and it is necessary to use a combination of different softwares inside a suite or different software proceedings from different vendors.

- Central method: using shared environment for both procedures, where "readability" of specific data is ensured by an interoperability gateway, such as the IFC format. Again, it is necessary to use a combination of different softwares inside a suite or different software proceedings from different vendors, and so interoperability is a crucial requirement of the digital model.

- $\quad$ Distributed method: performed by transferring data between the design tool and simulation tools via a middleware.

Most preferable among them, according to the literature review but also confirmed with the records of executed projects, is the central method, and it corresponds to the chosen approach in the TRAINEE project in order to express the benefits of BIM toward energy efficiency in buildings.

The training, which has delivered more than $110 \mathrm{~h}$ of lectures to approximately 60 professionals and companies, has introduced the trainees to the advantages of the use of BIM software tools Edificius and TerMus PLUS, as well as SolariusPV for photovoltaic systems design, provided by the Italian software developing company ACCA Software $[39,40]$. It was a wining decision to select ACCA Software as the software provider, as it is a buildingSMART winner of a professional software award for 2019 [41,42] and CDE platform award for 2020. The importance of this selected software consists in the possibility of editing IFC data and that it is an affordable software compared to other software options, something that is of vital importance for massive adoption in a sector such as architecture and engineering.

\subsection{Drafting National Roadmap for Impelementation of BIM}

The third action in the threefold approach is the preparation of a document that will act as a guideline for enabling national implementation of BIM. Some of the main characteristics that this document should have are defined according to the best practice experiences for other countries, identified through the literature review [19-21]. They are given in continuation.

\subsubsection{Strategic Goals of the National BIM Roadmap}

The specific objectives that support this vision, to trigger the challenges identified by the BIM survey, are set out below:

- $\quad$ engaging the governmental bodies as an investor in public construction works, thus acting as a leader in supporting BIM adoption, is expected to act directly on the increasing of the demand; 
- creation of a BIM certification body to support and enhance the training offer with defined training structure and content in terms of learning outcomes in order to ensure quality of the BIM skills offer;

- $\quad$ aligning proposed actions for digital transition of the national construction sector with EU and international regulation and guidelines will serve to facilitate adoption of international BIM standards, necessary to introduce a framework for a new digital approach in construction;

- $\quad$ involving all key enablers form different professional profiles to ensure a successful digital transition, thus supporting the building of a culture of collaborative projects.

These strategic goals will be evaluated upon achievement of key performance indicators (KPIs), defined in the official document of the National BIM Roadmap as quantifiable criteria for progress (success or failure). This strategic paper provides guidelines for the advancement of digital design and aims at optimization of the successful introduction of BIM.

\subsubsection{Main Stakeholder Groups}

Target groups of interested parties that should play a certain role in the process of implementation of BIM or take an advantage of digitization are grouped in three groups as follows:

- companies (construction companies, design studios, engineering firms, owners, developers ... );

- industry or professional bodies (manufacturing of construction materials and products, professional associations, engineering societies ... );

- government (public bodies, legal authorities, public education and training institutions ... ).

It is to be mentioned that the achievement of the above-listed objectives shall be orchestrated in collaboration with relevant governmental and non-governmental stakeholders' engagement to ensure successful implementation of the proposed measures.

\subsubsection{Types of Action and Fields of Action toward BIM Adoption}

Based on the findings of the national BIM survey and knowing the current situation of the construction sector in the country regarding the level of digitization (the level of awareness of existing digital tools and the benefits of their use), as well as taking into account the available professional workforce and their interest and potential for adopting digital tools in their work (as expressed in the BIM survey), the identified necessary types of action toward introduction and wider BIM adoption are summarized as presented in Figure 4.

Current status regarding BIM

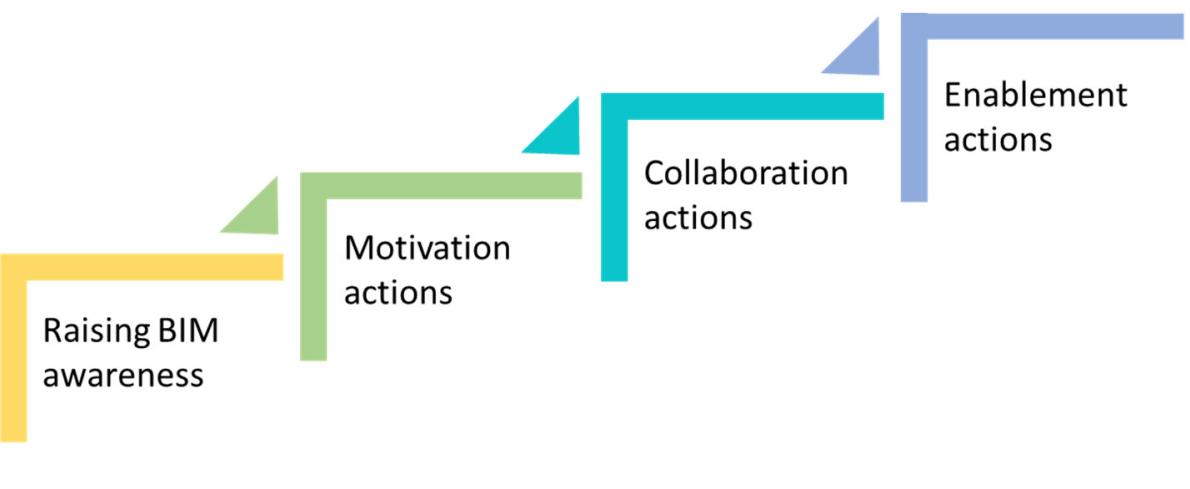

Figure 4. Proposed types of action toward BIM adoption in the National BIM Roadmap. 
The actions proposed to achieve step-by-step introduction of BIM on national level are elaborated by types of action that correspond to WEF's proposed actions for BIM adoption [6]. These types of action can be distinguished into two groups: passive measures—not leading toward initialization of implementation of BIM but rather prerequisites for starting with implementation of the next group of proactive measures that occasionally will result in a systematic approach ensuring positive output. Here, awareness-raising activities are on the midway of the whole process, acting as a milestone and transition point between passive and proactive measures.

The above-mentioned types of action are to be taken in different "sectors of influence" - fields of action that will ensure coordinated driving force toward successful introduction of BIM on the national level. The necessary fields of action when pathwaying national BIM adoption, as defined by the WEF, are:

- Leadership

- Standards

- Education and training

- Procurement

\section{Results and Discussion}

\subsection{The Analysis of Survey Data and Discussion}

The data obtained through the survey were analyzed statistically and described by percentages, proportions, graphs, and charts for comparing the level of knowledge of AEC industry practitioners. The questionnaires aimed at gathering information in the following topics:

1. types of building professionals;

2. tools for BIM design; and

3. barriers/obstacles for increased BIM use.

The survey about penetration and acceptance of BIM practice shows that the most concerned by BIM software tools are architects and engineers, for their design purpose. Construction and renovation of buildings in residential and public sectors are shown to be more relevant, because over $70 \%$ of respondents belong to this sector, in comparison to the infrastructure sector. Half of the respondents have heard of BIM software tools, but only $2.5 \%$ are fully focused on delivering all of their designs in BIM. Most of these architects and engineers generally use two commercial software tools, Graphisoft ArchiCAD and Autodesk Revit. No openBIM tools or other alternatives were known to most of the respondents.

In the next section, descriptive statistical values for presenting the survey findings are given. The data gathered from the respondents presented in Table 4 demonstrate the descriptive statistics for the level of usage of BIM measured by a semi-Likert scale; illustrated are the mean and standard deviation of the findings based on the answers to questions related to the subject of usage of BIM. We introduce this modified application of the Likert scale to express the statements in terms of measurable values, marking with the highest value a strong agreement (or approval and acceptance) and with the lowest value the most negative attitude. Although this is not a standard use of the Likert scale, this analysis can give a quantitative impression of the attitude of the respondents and express trends of distribution of opposite statements.

Table 4 summarizes the conclusions that, in general, the respondents are interested in using BIM technology; however, its use is still not in place. From the respondents that are already familiar with the technology, most of them have declared themselves as advanced users, while the strongest deviation of the answers is shown for the question related to the origin of the initiative for starting with BIM implementation, where the majority have answered that it was on their own initiative. 
Table 4. Statistics for the level of usage of BIM measured by a semi-Likert scale.

\begin{tabular}{|c|c|c|c|c|c|}
\hline Semi-Likert Scale Value & 3 & 2 & 1 & & \\
\hline \multirow[t]{2}{*}{ Do you use BIM? } & Yes & Still not, but I am interested & No, not interested & Mean & SD \\
\hline & 24 & 201 & 87 & 1.79 & 1.32 \\
\hline \multirow[t]{2}{*}{ Level of expertise } & Expert & Advanced & Beginner & & \\
\hline & 5 & 10 & 9 & 1.83 & 1.44 \\
\hline \multirow[t]{2}{*}{ Behavioral attitude } & My own initiative & Investor & Employer & & \\
\hline & 19 & 3 & 2 & 2.71 & 2.24 \\
\hline
\end{tabular}

The findings related to the behavioral attitude of the respondents regarding intentions for future use of BIM are presented in Figure 5a. The respondents show a strong belief that the introduction of BIM will come in the very near future (according to the answers, in the next 1-2 years), but the findings that can easily be listed as barriers to the introduction of BIM state very explicitly that currently the major problem for wider BIM adoption is the lack of demand by clients (Figure $5 b$ ).

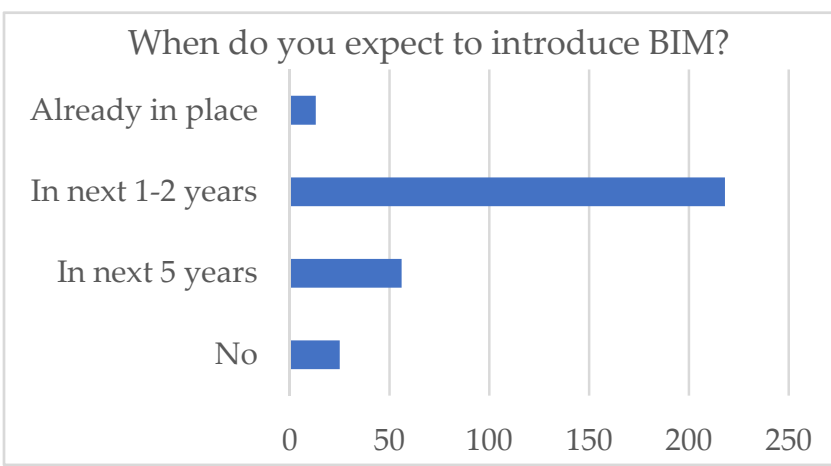

(a)

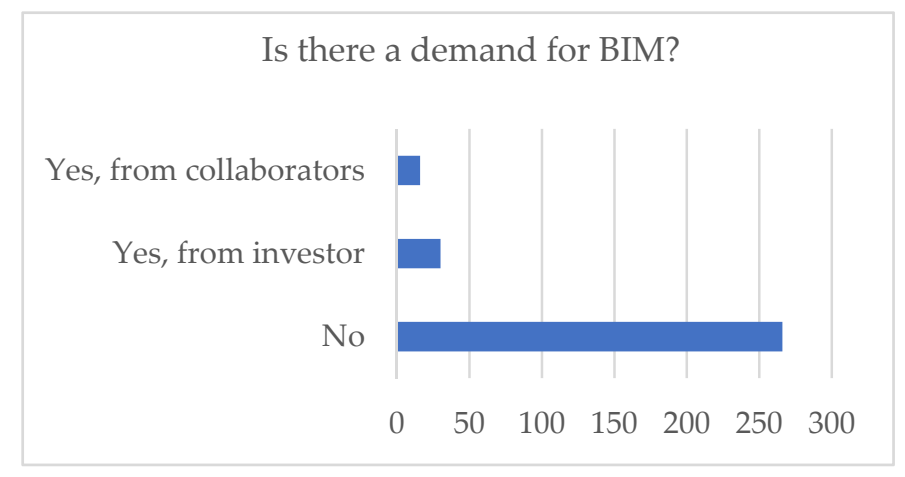

(b)

Figure 5. Attitude toward using BIM. (a) The intention to use BIM in the near future; (b) the existence of request for BIM.

Furthermore, the identified barriers for more intense introduction of BIM are identified and discussed. Figure 6 presents the radar chart of six sources that hamper BIM adoption, identified by the respondents of the survey, and their weight in terms of percentage of respondents that have chosen a certain option as the most important one. Here, it is to be emphasized that only one option identified as the most important could be selected.

The survey has identified challenges for further BIM adoption that correspond to the common conclusions on this topic, as is also the case also in other international studies. Maybe the most evident is the challenge to make a big switch from traditional to digitally driven construction. This requires changes in attitude, resulting from much harder introduction of new things in more traditional environments. The identified specific issues hampering the implementation of BIM are the lack of skilled professionals, the lack of BIM training, very low demand from market actors, and high initial cost for implementation of BIM standards and specifications. There are very limited courses teaching BIM-related software tools in North Macedonia. However, these training options are mostly commercial ones, available from one authorized training provider of Autodesk that offers training in only one specific BIM software, such as REVIT. Because the scope of this study did not cover exploring the presence of BIM in training programs in formal education (including vocational education for construction and architecture and academic studies in these fields), more profound study on the existing BIM programs in formal education was not conducted. However, the fact that there are no courses at the university level entirely devoted to BIM (or titled as so) is indisputable. There are only some parts of programs related to the issue of 
digital construction, covered with the syllabuses of other academic courses, mainly dealing with management of construction.

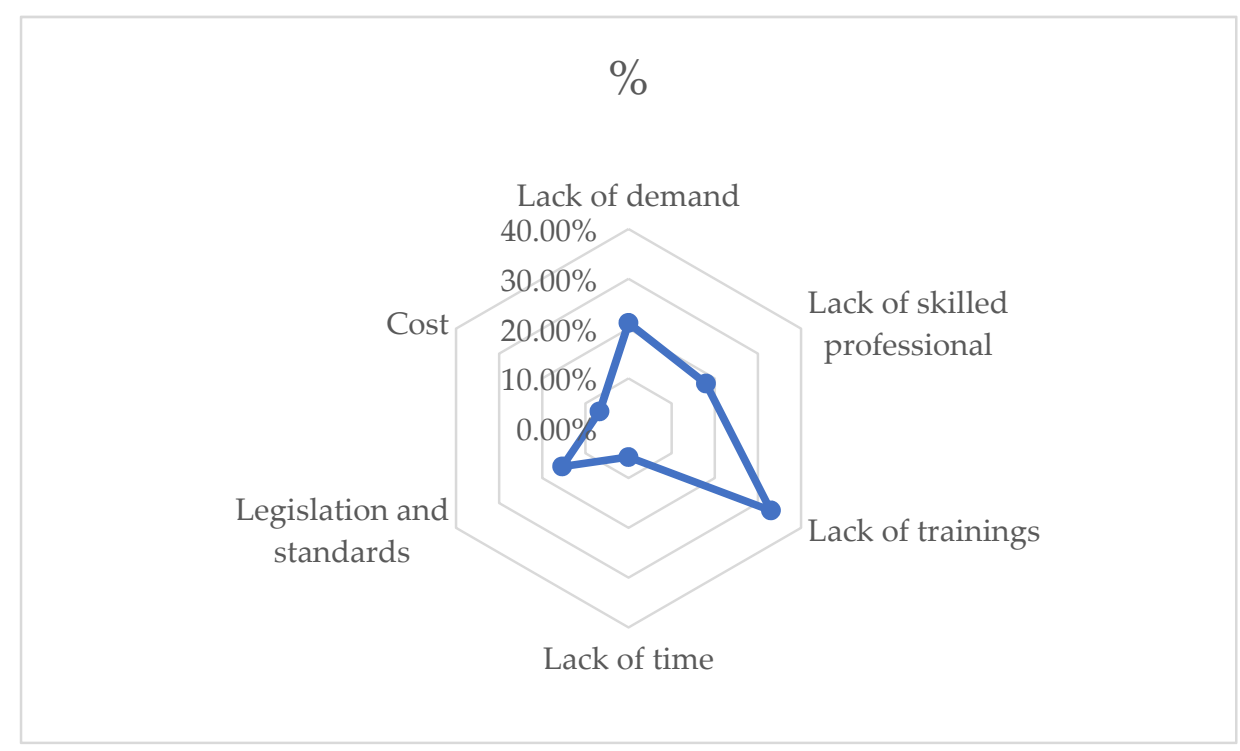

Figure 6. Barriers for BIM adoption identified during the BIM survey in North Macedonia, adapted from Ref. [34].

Main Conclusions and Recommendations upon Survey Results

The survey results gave a clear picture of where the focus should be placed in order to achieve successful introduction and acceptance of BIM practice.

Three major barriers that were detected through the survey are [35]:

1. lack of BIM training (33\%, or 103 respondents);

2. insufficient requests from clients (no demand for BIM design) (21.2\%, or 66 respondents);

3. missing standards and guidelines (15.4\%, or 48 respondents)

The survey about penetration and acceptance of BIM practice shows that the most concerned by BIM software tools are architects and engineers, for their design purpose. Buildings are most appropriate for the introduction of BIM tools, because over $70 \%$ of respondents belong to this sector. Half of the respondents had heard of BIM software tools, but only $2.5 \%$ were fully focused on delivering all of their designs in BIM. Most of these architects and engineers have educated themselves on their own initiative for generally two commercial software tools, Graphisoft ArchiCAD and Autodesk REVIT. No openBIM tools or other alternatives were known to most of the respondents. Still, the low or nonexistent demand results in BIM trainees themselves being resistant and reluctant to learn new tools and workflows, as they perceive this as a waste of time and a hindrance to their productivity. The biggest challenge is to increase the diversity of BIM training options, enlarging the demand side, which will lead to higher penetration of BIM in the private sector, and this, from the other side, can easily lead to its implementation in the public sector and national legislation. Continuous education and training of employees are invoking real costs that could influence introduction of BIM standards. We always must have in mind that even the most proficient BIM user will need to learn continuously and evolve with their knowledge.

\subsection{Discussion of the Results of Case Studies Using BIM in Achievement of Energy Efficiency BEM}

\subsubsection{The Scope of Realized Case Studies}

Two case studies were conducted and are briefly presented below. It is important to fix the concepts that help to achieve better energy consumption through all phases of the 
building life cycle. Proper studies are necessary to maximize the saving while keeping energy consumption at the minimum level at the same time.

The first case study aimed at showing that proper urban planning can help to take advantage of suitable location, orientation, less shadowing (self-one or projected by neighboring buildings), and urban regulations favoring energy efficiency (number of glass openings, possibility to create balconies, terraces, flat roofs, acceptance of solar appliances and photovoltaic panels, etc.). When urban planning is fixed, the design process cannot vary these conditions, and these conditions could be easily checked through e-permit evaluation (the EUnet4DBP-European Union net for Digital Building Permits has made visible the importance of geographic information systems (GIS) and BIM connection for these parameters). This concept, called "intelligent communities life cycle" in the case of North Macedonia, is extremely useful, as one of the greatest shares in energy consumption is in public heating combined with private heating, one specific and very interesting energy mode in continental countries.

This "public energy consumption" makes it difficult to extract the exact bill for apartments and for housing blocks, and so a measure taken in this sense will be impossible to track per single use. Thus, the approach had to be changed toward developing sustainable communities through performance analysis solutions. This would have to be converted into individual building analysis that could permit there to be a counter per building instead of per user, enabling the design of new buildings as well as renovations that will lead to significantly less energy consumption, while maintaining occupant comfort. This situation means that personal behavior toward energy savings has to be extrapolated to "community" behavior, quite more difficult to track, empower, and enhance. Larger groups of buildings designed as residential homing blocks and neighborhoods will better apply these energy design concepts to entire communities and not just individual flats or single housing [42-51].

\subsubsection{The Approach for Analysis of Case Study Results}

TRAINEE has focused on the PV energy modeling proposal (as clean and $\mathrm{CO}_{2}$-free energy, which works perfectly in cold and sunny countries, such as North Macedonia) and probably could have a second part for monitoring and analysis and considering how it can be integrated into a digital twin and a building digital twin for sustainable design. This approach will be more and more important, as we need SDGs (sustainable development goals) settled by the UN in 2015 to be globally achieved in 2030, net-zero buildings by 2050 in the UK and Europe, AIA 2030 Commitment in US, etc. In most cases, the communities that need to be reconfigured with PV solar systems to reach these goals are already built, and their share with respect to new buildings is significant [43-45]. TRAINEE has been focused on both fields: one to retrofit existing buildings with solar systems and one to help architects and engineers to simulate energy gains and losses in new building designs. The application of BIM in both fields is slightly different; for the first case, we have to create a BIM model using techniques such as laser-scan, plus the transformation of a point cloud into a digital BIM model, and then applying the energy consumption to the model (as in a new housing scheme) $[52,53]$.

Case studies were performed as six-phase activities on two different concepts of buildings: block housing and single (individual) house.

- Phase 1 is based on selecting the housing block or the new design of a single house (Figure 7a).

- Phase 2 (Figure $7 \mathrm{~b}$ ) takes into account the existing conditions of the physical context (latitude, weather, solar orientation, wind, existence of rivers, mountains, and neighboring buildings).

- $\quad$ Phase 3 is based on the calculation of existing solar irradiation from meteorological data from Meteonorm, PVGIS, or Macedonian Geologic Institute. In the TRAINEE program, Solarius PV by ACCA Software has been used to estimate the photovoltaic 
solar production from real data of the solar irradiation available, acquired from the main reference climate databases and its deployment in terraces or tilt roofs.

- Phase 4 configures the automated drawing of the single-line electrical diagram of the photovoltaic installations, having the option of customization with the addition of electrical panels (in AC and DC), electrical protections on the output or input, types of cables, etc. This single-line electrical diagram of the photovoltaic system installation is represented in a complete plan with general data and legends of graphic symbols with details of the types of components used and is ready for printing or export in PDF, DXF, DWG, etc. formats.

- Phase 5 explores the tracking of consumption per hour, day, week, month, trimester, quarter, and / or year.

- $\quad$ Phase 6 fixes the energy savings (Figure 8a) and money flow control (Figure 8b). Money flow control is a very important issue, as it can be the driver to make the investment or not. Normally, the investment will be made if it is self-paid or if the recovery of the investment, commonly called ROI, or return of investment, is made in a very short number of years. Long recoveries or high investments make difficult the acceptance of the change to other kinds of energies.

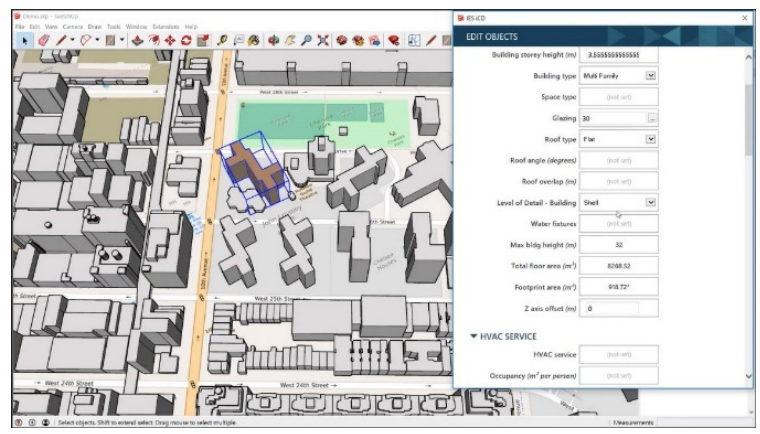

(a)

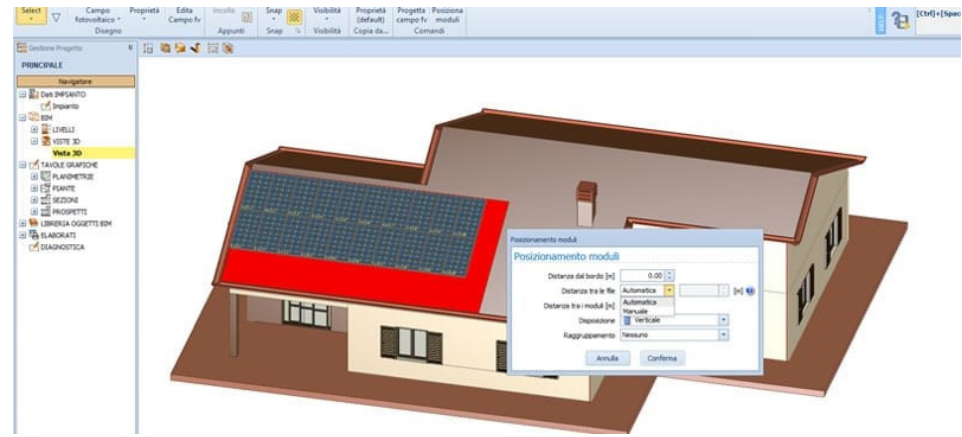

(b)

Figure 7. Procedures for realization of case studies: (a) Phase 1: selecting the object for BEM analysis; (b) Phase 2: physical context of the selected object, adapted from Ref. [41].

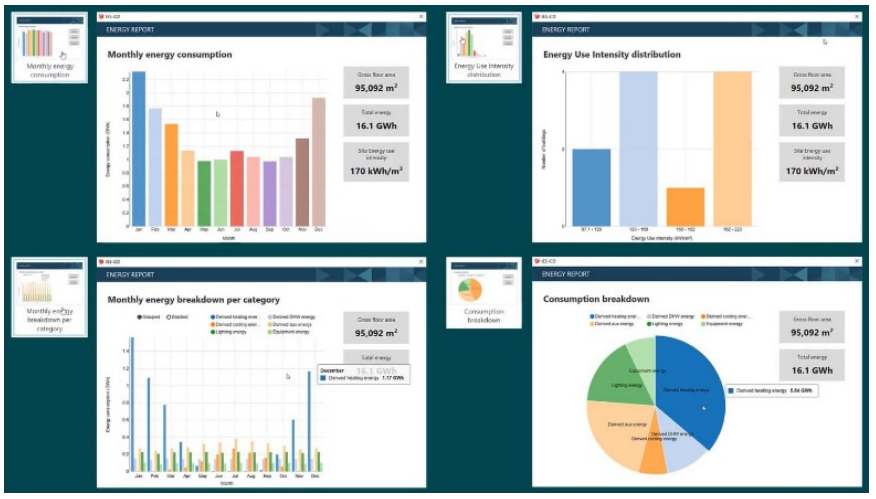

(a)

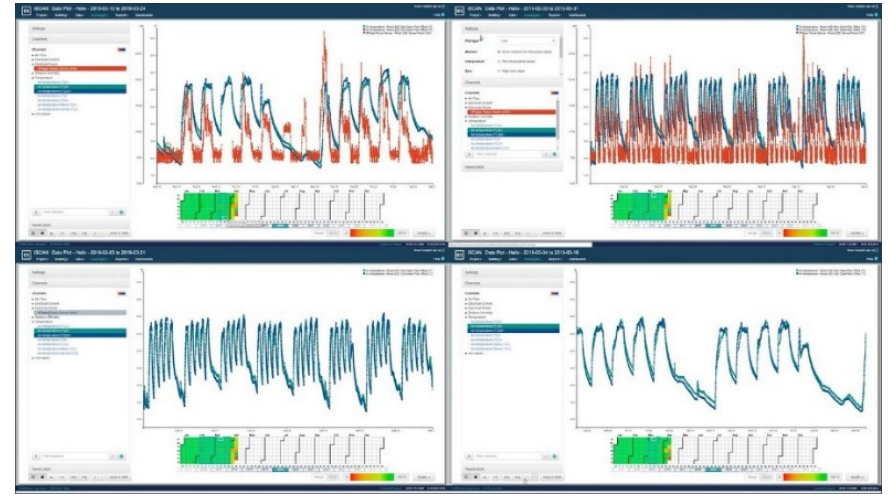

(b)

Figure 8. Phase 6 of realized case studies: (a) representation of energy consumption; (b) control over costs (money flow), adapted from Ref. [41].

\subsubsection{Interpretation of the Case Study Results}

The two case studies referred to different types of buildings: block housing (Figure 9) and single (individual) house, both located in Skopje, North Macedonia. The tasks involved creation of an optimized model integrated with BIM and combination of tools to enable modeling of the energy performance of the buildings. 


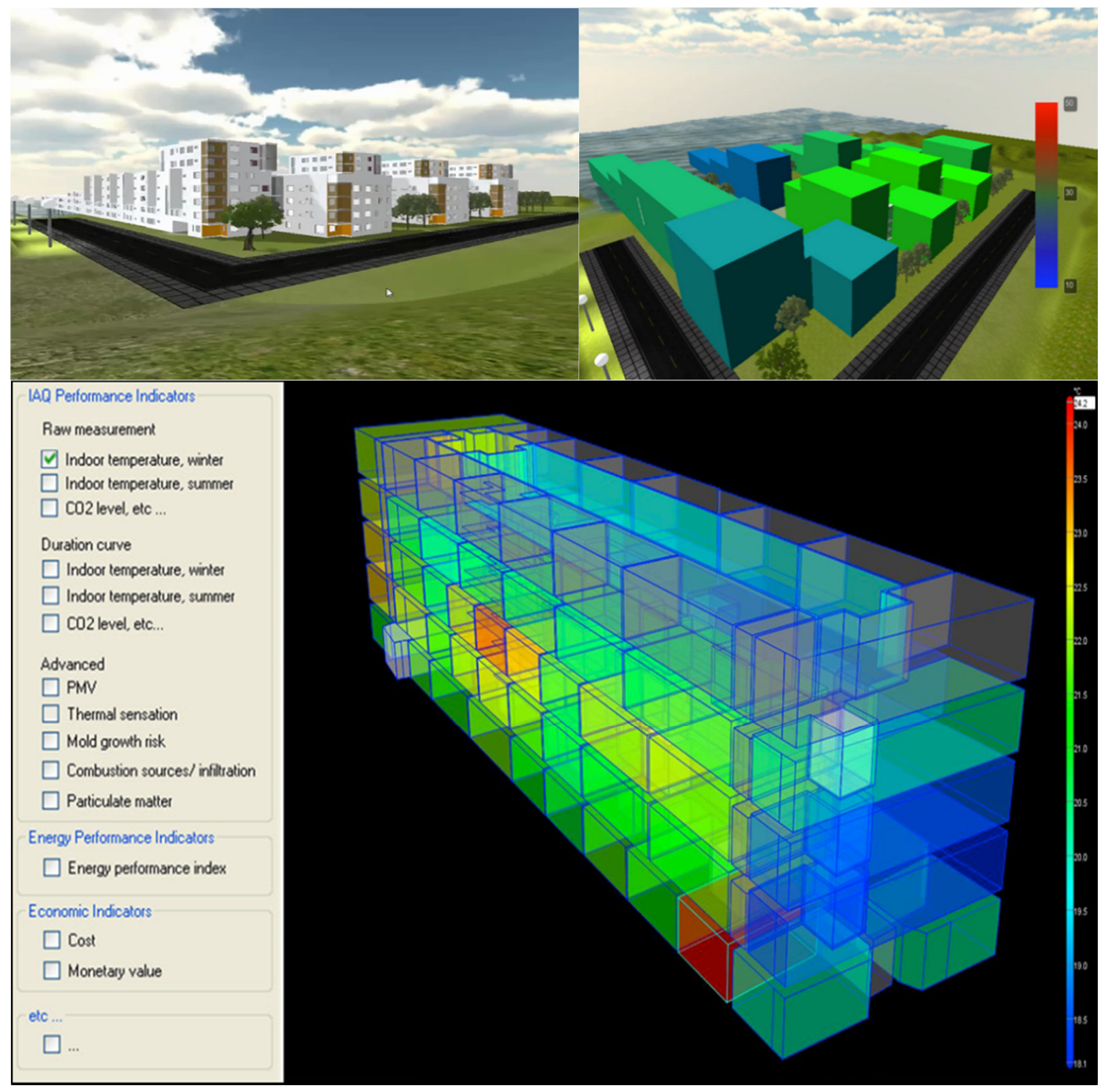

Figure 9. Case study no. 1 for expressing use of BIM in energy modeling: building block in Skopje, North Macedonia.

The central method for integrating BIM and BEM was used through a shared environment for both procedures, using specific data in IFC format. IFC provides an environment of interoperability among IFC-compliant software applications in all phases of building design, construction, and maintenance [44].

The assessment levels were comprised as optimization stages:

- $\quad$ BIM model (IFC/ACCA Software + Edificius)

- $\quad$ Energy model (SolariusPV)

- $\quad$ Optimization software multi-objective building optimization (TerMusPLUS)

For the second case study on the single house, the goal was to identify the best comfort, energy, and cost scenarios by using a simulation model for the purpose of building refurbishment (Figure 10). The experiment was simulated at a passive level, considering vernacular strategies of the southeastern EU regions, such as natural ventilation and the use of sun protection (comfort-economic). The model is used to find the optimum with active systems, applying cost-optimal criteria of energy and economic efficiency. A second further 
stage could be to introduce environmental labeling for the different grades of comfort, as in PassivHaus, BREEAM, Minergie, HQE, LEED, dgnb, VERDE, or WELL, to create an evaluation of the needs for each label, and a next phase could be the adoption of proper tracking with IoT (Internet of things) sensors, connected to the BIM and BEM model to identify which communities, blocks, or apartments are better or worse energy users.

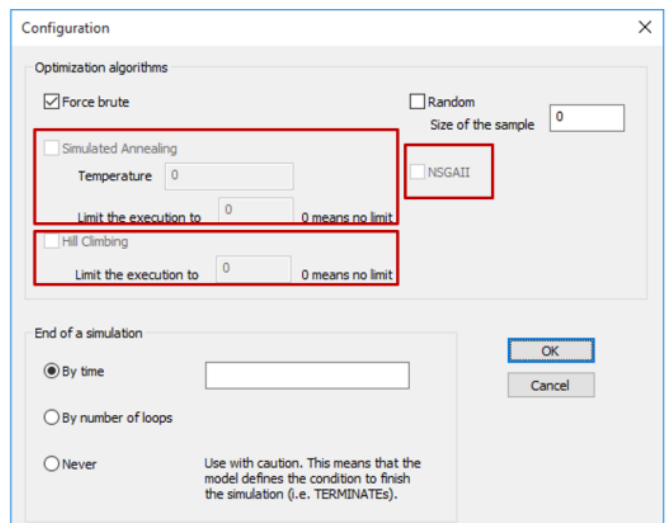

(a)

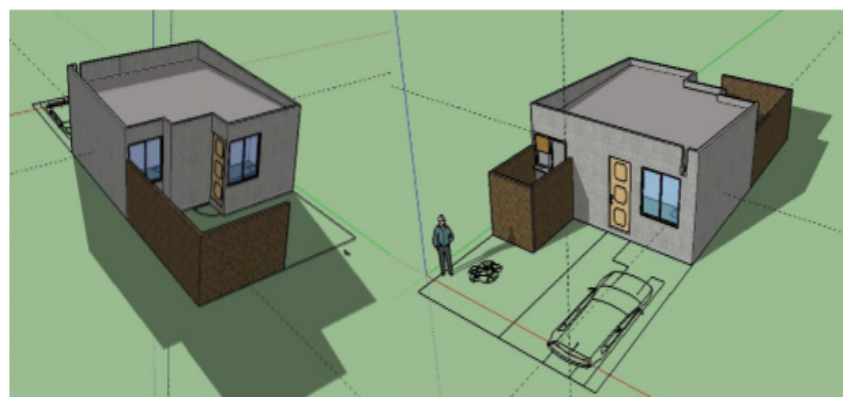

(b)
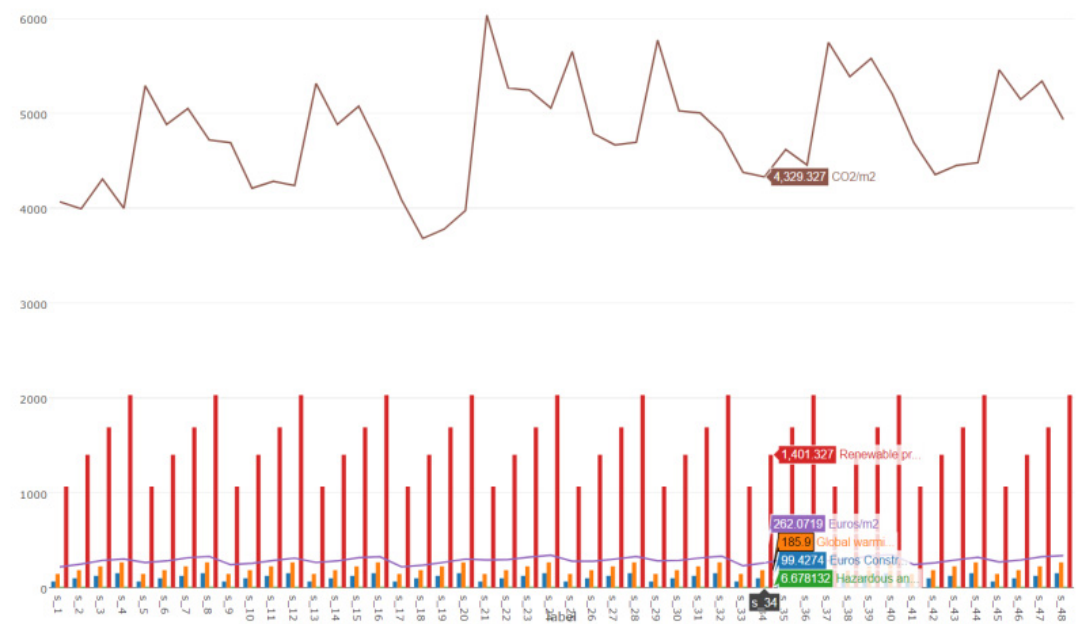

(c)

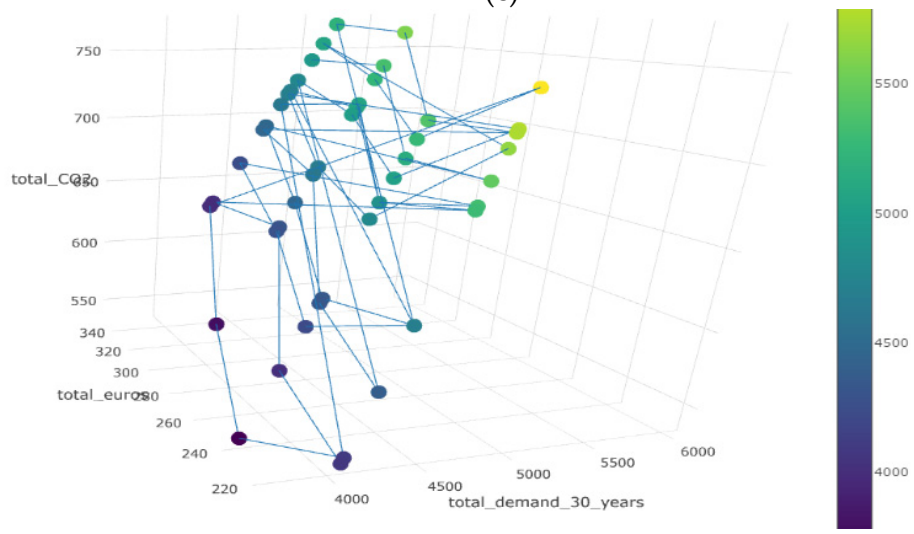

(d)

Figure 10. Case study no. 2 for expressing use of BIM in energy modeling: individual house in Skopje, North Macedonia. (a) Configuration of geographical location; (b) conceptual design from BIM model and checking for solar radiation and shadowing and first visual checker of PV and solar paneling location; (c) actual energy consumption and environmental impacts calculated with BEM; (d) estimated predictions for future building performance using BEM. 


\subsubsection{TRAINEE's Digital Procedure to Implement BEM Digital Models}

These case studies have served the purpose of expressing the usability of BIM in performing energy modeling of existing buildings. The TRAINEE project has created a digital procedure to implement BEM digital models in housing communities to track their consumptions and savings (Figure 11). Implementation of the procedure is pending. It was shown that even when the building itself is not initially constructed with a BIM model, converting the existing building data into a digital model can serve for modeling the future building performance and selecting the retrofitting interventions that will satisfy the cost-gain ratio. The transformation of all housing communities into digital models to manage their energy consumption on a real-time basis after a PV and solar paneling intervention will be the next challenge.

\section{TRAINEE savings procedure:}

\section{How to save energy and generate energy}
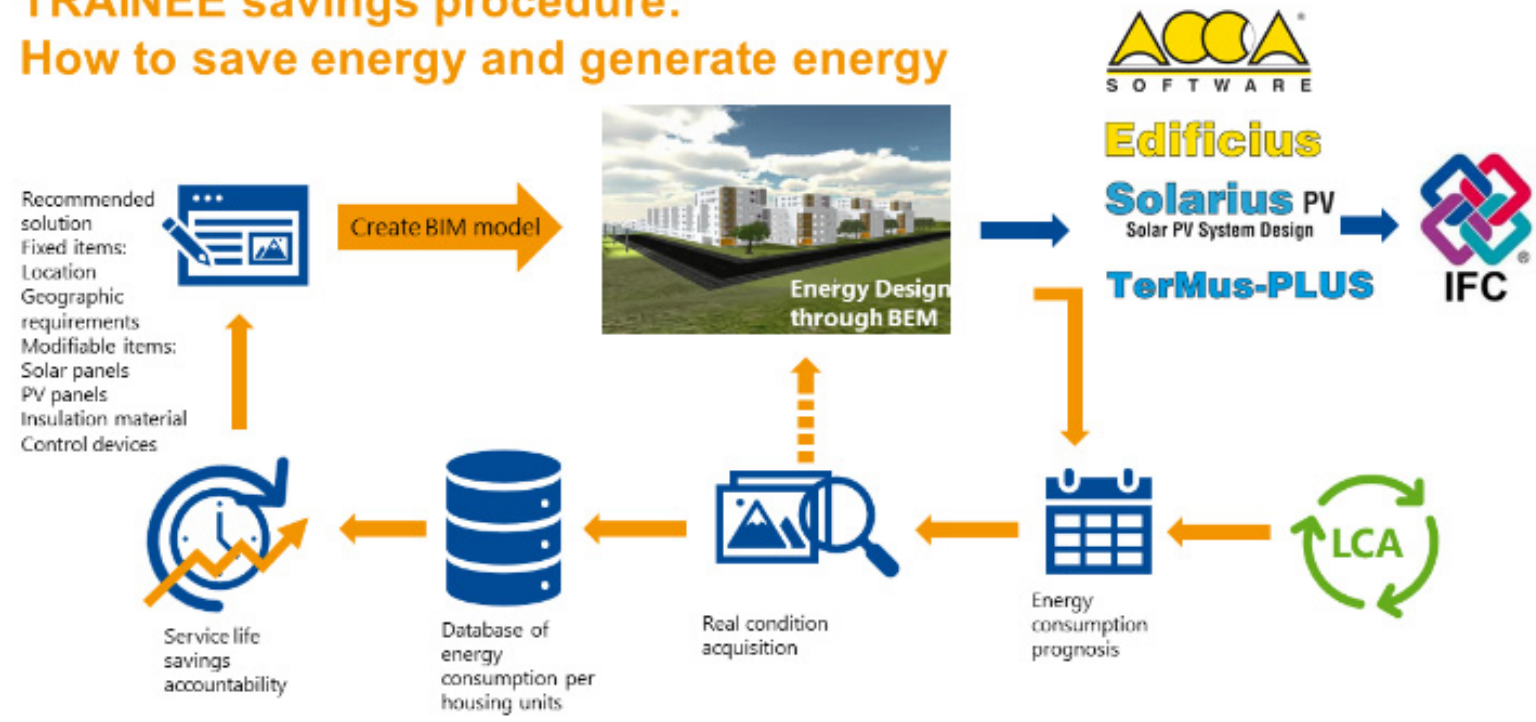

Figure 11. Digital procedure to implement BEM digital models in housing communities developed by TRAINEE project to track energy consumptions and savings.

The real savings numbers after one BEM design in a real community or block housing and its tracking and counter-comparison are pending, but the expected figure is that digitizing the housing sector by using BIM and BEM can serve to track the energy consumption trends and to identify the measures that can result in final energy savings. It is expected that significant numbers of up to $20 \%$ in energy savings for new buildings and up to $38 \%$ with retrofitting of existing building stock can be achieved through the proposed procedure.

\subsection{Proposal of a National BIM Roadmap}

\subsubsection{Structure of the Proposal of the National BIM Roadmap}

The proposal of the set of measures and actions that should lead to a more structured, governed, and coordinated approach toward BIM implementation on a national level is designed to engage all relevant stakeholders and to entitle the leading role of representative organization (body), where the government itself should take its responsibility, at least in establishing such a coordinating body (if not taking the role itself) [45].

The set of measures are chosen from the types of action previously identified and are spreading through all four fields of action (Figure 12) in order to guaranty in-depth penetration in all relevant spheres and to ensure a stable fundament for transition from traditional to digital construction. The proposed strategies and actions are targeted to overcome barriers identified in the BIM survey. The basic structure of the proposed roadmap is shown on Figure 12. 


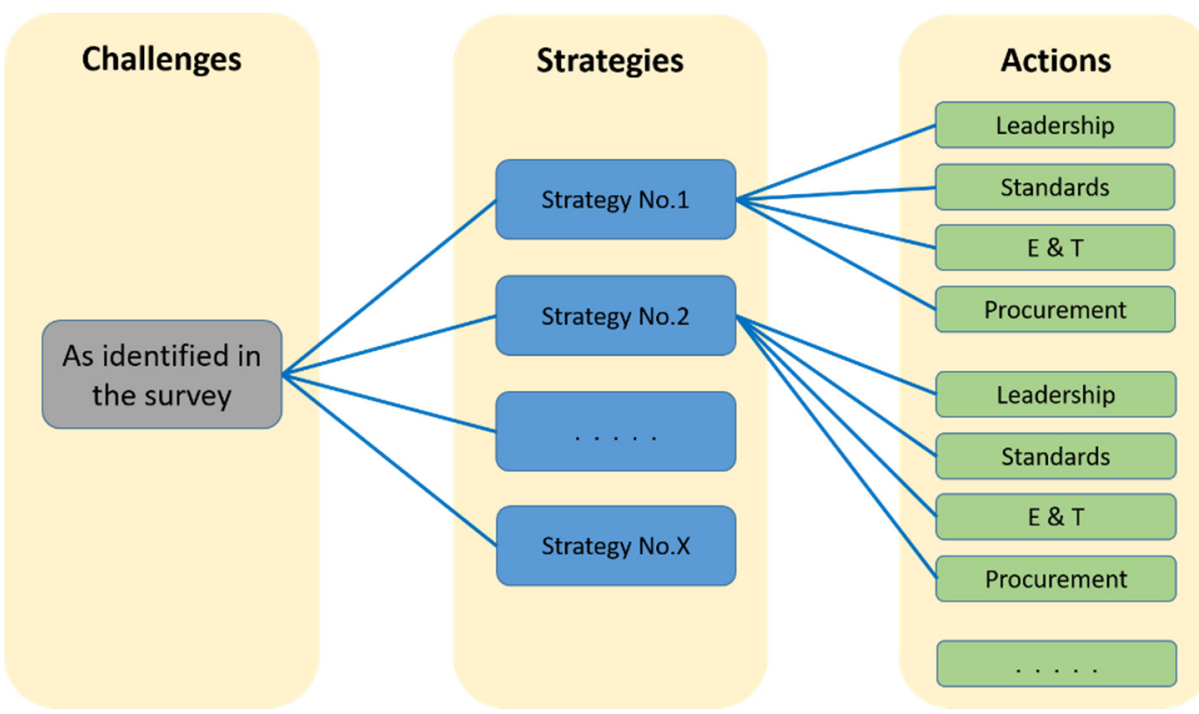

Figure 12. Basic structure and fields of action of the proposed BIM roadmap.

The detailed structure of the roadmap is then presented in Appendix A. It describes the relevant strategy proposed for meeting the identified challenges and the adequate measures set to mitigate the barriers, which are all listed in corresponding vertical columns of the graphical representation of the roadmap. Measures are to be undertaken in all four fields of action as indicated in the corresponding horizontal lines representing the listed measures. The roadmap also indicates the expected timeframe for the implementation of a certain action. It is expected that the proper implementation of well-planned measures can bring the digitization of the construction sector on a significantly higher level in the timeframe of four years.

\subsubsection{General Recommendations for National BIM Adoption}

The proposed roadmap for BIM adoption aims at triggering the attention of the responsible public and governmental authorities to be more proactive toward pushing the digitization of the national construction sector forward in order to keep pace with developed countries and global development. This document should act as a baseline and template document to define the step-by-step process of digital transformation and to delegate the roles of all responsible actors in the process. The document is structured by summarizing the best approaches and successful practices of developed countries and offers the structuring of a system of measures that can lead to the achievement of defined goals in collaboration with all relevant governmental and non-governmental stakeholders.

Based on the experience of developed countries that have been successful in implementation of BIM and are already harvesting the benefits that follow after the phase of "initial implementation", general recommendations that ensure success of the process of BIM adoption can be formulated as:

- introducing a BIM mandate is shown as a successful push forward incentive;

- clear framework for procurement of BIM in public sector construction projects is a positive approach;

- identifying a champion for BIM. Acting as a central figure in the process of initiating BIM adoption, the BIM champions are recognized by supporting BIM adoption and providing profound expert advice to overcome appearing challenges.

Better integration of BIM tools is necessary in order to achieve these goals and report energy savings. A European Commission study finds that the most successful countries in this area are the ones that have integrated BIM requirements into their public procurement legislation and that supported the implementation of BIM through public sector interventions in a more effective way if they are in line with private sector initiatives [31]. 
The regulatory environment will also define the potential for change, and, in order to support productivity growth, regulators may mandate the use of BIM to increase transparency and cooperation across the industry; publish supplier performance data; create cost transparency throughout the construction industry; transform regulations to support productivity; and consider labor interventions to ensure skills development instead of relying heavily on a cheap migrant temporary workforce [1].

\section{Conclusions}

BIM is definitely promoting serious changes to the construction industry. It changes its perspectives, its standard procedures, its way of traditional functioning, but BIM brings its own potential to harvest benefits in all stages of the project life cycle.

According to the findings of the survey, it had been shown that BIM is still in a premature level of implementation in North Macedonia. Although there are individual successful examples, the sector is not prepared, and the whole picture has to be created with thorough planning and activating stakeholders of all levels of the construction sector and, even more importantly, the relevant authorities and market actors. Transformation toward BIM as a new technology and methodology for executing construction in all phases requires a strategic plan. In order to achieve BIM's full adoption, enforcement by the government is needed. At the early stage of implementation, the enforcement by government toward $\mathrm{BIM}$, as a driver for the required change, is necessary.

Showing successful examples, promoting benefits, and changing the culture of traditional construction are only some of the measures that guarantee change of perception and eagerness for embracing the positive changes.

\section{Limitations and Further Studies}

This work presents the current stage of implementation of BIM in the Macedonian construction sector. It includes an insight into the current attitude of the professionals and workers in the sector toward BIM implementation, identified through a conducted survey presented as the first pillar of the paper's actions. However, the results obtained by the survey should be considered by taking into account the limitations of this study, related to the total response rate of the target sample. As stated in Section 3.1.1, from the total of 57,000 employees in the national construction sector, the sample size of contacted respondents sent questionnaires was 1500 , i.e., $2.6 \%$ of the total sample size. The obtained 312 valid responses represent a $20.8 \%$ respondent answer rate relative to the sent questionnaires, but it is an even lower answering rate relative to the total sample size. This should be considered as the frame of the survey's limitations.

Although this study is among the first dealing with this subject, it opens many different fields for further, deeper research, it raises new questions and uncertainties and requires precise analysis and evaluation of the adequacy of some internationally recognized and accepted approaches to correspond best to the national circumstances.

Some of the plans for future studies are already elaborated in the main text of this work, as they become evidently necessary through discussion of the achieved results of the performed work while identifying the uncovered area of this study. These ideas will be listed in brief, organized according to the three axes targeted by the paper:

(a) Future steps to improve the BIM survey will be to spread its scope to other respondents from the group of BIM users (not BIM professionals), to collect information on the construction phases where the use of BIM is mostly present, and, of greatest importance, to investigate in more detail the inclusion of BIM in formal education programs in order to be able to propose appropriate actions to overcome skills shortages.

(b) Regarding the use of BIM in evaluating the energy performance of buildings (both new and already constructed), there are several directions to extend this study. After developing a PV energy modeling procedure, the next part of the study could be dedicated to monitoring and analyzing how they can be integrated into a digital twin and a building digital twin for sustainable design. Then, the introduction of 
environmental labeling for the different grades of comfort is a useful way to express the building's value, and the third direction for further studies could be converting the existing building data into a digital model to serve for modeling the future building performance and for selecting the retrofitting interventions that will satisfy the costgain ratio.

(c) Considering the proposed document for the National Roadmap for implementation of BIM that elaborates strategic actions designed to support sustained use of BIM, it is necessary to continuously monitor and evaluate the effectiveness of its realization. This will ensure that the pace of development is well defined, ensuring keeping track with the objectives.

This threefold area for further studies guarantees that the interest to invest in BIM development is in the upward position and will ensure new achievements in the topic of BIM. It will also serve the sustainability of the paper's results as it opens field for further research and reveals the unanswered questions and challenges that the national adoption of BIM is facing.

Author Contributions: This is a joint research article with individual contributions of the authors as follows. Conceptualization, L.S.-G. and H.S.; formal analysis, L.S.-G., I.S., A.K., M.G., I.P. and R.I.; methodology, L.S.-G., I.P., T.C., and T.F.; resources, L.S.-G., I.S., A.K., M.G., I.P. and R.I.; software, I.P.A.; visualization, I.P.A.; writing-original draft, L.S.-G. and I.P.; writing-review and editing, L.S.-G., R.I., T.C. and T.F. All authors have read and agreed to the published version of the manuscript.

Funding: This research was funded by the project 785005-TRAINEE-H2020-EE-2016-2017/H2020-EE2017-CSA-PPI, and the conference presentation at SP2021 was supported by the project 101033743 SEEtheSkills-H2020-LC-SC3-2018-2019-2020/H2020-LC-SC3-EE-2020-2.

Institutional Review Board Statement: At the time when the survey involving participation of respondents was conducted, there weren't any institutional requirements for requesting an approval. However, the survey was conducted in accordance with the Declaration of Helsinki, following EU GPDR rules and the ethics principles of the project TRAINEE.

Informed Consent Statement: Informed consent was obtained from all subjects involved in the study, as anonymous survey participants.

Data Availability Statement: Not applicable.

Conflicts of Interest: The authors declare no conflict of interest.

\section{Appendix A}

Table A1. The summary of the proposed National Roadmap for introduction of BIM.

\begin{tabular}{|c|c|c|c|c|}
\hline Challenges & Strategies & Actions & Timeframe & $\begin{array}{l}\text { Field of } \\
\text { Action }\end{array}$ \\
\hline \multirow{8}{*}{$\begin{array}{l}\text { Lack of } \\
\text { demand }\end{array}$} & \multirow{4}{*}{$\begin{array}{l}\text { Public sector taking } \\
\text { the lead }\end{array}$} & Incentives for BIM requirements in all public works & 1st year & Leadership \\
\hline & & $\begin{array}{c}\text { Coordinated asset information requirements } \\
\text { across public sector }\end{array}$ & 2nd year & Standards \\
\hline & & Training schemes for public sector & 1st year & E\&T \\
\hline & & BIM mandates in procurement of public works & 2nd year & Procurement \\
\hline & \multirow{4}{*}{$\begin{array}{l}\text { Establish central } \\
\text { body }\end{array}$} & $\begin{array}{c}\text { Identify a suitable individual/executive to lead the } \\
\text { implementation program }\end{array}$ & 1st year & Leadership \\
\hline & & $\begin{array}{c}\text { Communication between BIM body and national } \\
\text { standardization agency }\end{array}$ & 1st year & Standards \\
\hline & & $\begin{array}{c}\text { Specifying BIM competencies when accrediting BIM } \\
\text { program }\end{array}$ & 2nd year & $\mathrm{E} \& \mathrm{~T}$ \\
\hline & & $\begin{array}{c}\text { Make provision for developing government } \\
\text { construction contracts }\end{array}$ & 2nd year & Procurement \\
\hline
\end{tabular}


Table A1. Cont.

\begin{tabular}{|c|c|c|c|c|}
\hline Challenges & Strategies & Actions & Timeframe & $\begin{array}{c}\text { Field of } \\
\text { Action }\end{array}$ \\
\hline \multirow{14}{*}{$\begin{array}{l}\text { Lack of BIM } \\
\text { skills (both } \\
\text { training and } \\
\text { skilled pro- } \\
\text { fessionals) }\end{array}$} & \multirow{3}{*}{$\begin{array}{l}\text { Promoting success } \\
\text { cases }\end{array}$} & BIM competitions & 2nd year & Leadership \\
\hline & & Scholarships for BIM education & 2nd year & E\&T \\
\hline & & $\begin{array}{l}\text { Mandate for skilled BIM professionals for } \\
\text { government projects }\end{array}$ & 3rd year & Procurement \\
\hline & \multirow{4}{*}{$\begin{array}{l}\text { Building BIM } \\
\text { capacities }\end{array}$} & Awareness seminars & 1st year & Leadership \\
\hline & & BIM center of excellence & 2nd year & Standards \\
\hline & & Developing self-assessment tool for BIM skills & 1st year & E\&T \\
\hline & & BIM R\&D actions & 3rd year & Procurement \\
\hline & \multirow{3}{*}{$\begin{array}{l}\text { Developing BIM } \\
\text { education and } \\
\text { training }\end{array}$} & $\begin{array}{l}\text { Develop a base level of learning outcomes targeted at } \\
\text { alternative } \\
\text { NFQ levels }\end{array}$ & 1st year & Leadership \\
\hline & & $\begin{array}{c}\text { Develop a BIM certification program to be managed } \\
\text { by the } \\
\text { National Standards Authority }\end{array}$ & 2nd year & Standards \\
\hline & & BIM in Schools and universities & 3rd year & E\&T \\
\hline & \multirow{4}{*}{$\begin{array}{l}\text { BIM certification } \\
\text { and connection } \\
\text { with NQF }\end{array}$} & $\begin{array}{c}\text { Leveling of BIM skills with NQF levels and creation } \\
\text { of BIM occupational standards }\end{array}$ & 2nd year & Leadership \\
\hline & & $\begin{array}{c}\text { Links with international standards for BIM } \\
\text { certification }\end{array}$ & 3rd year & Standards \\
\hline & & $\begin{array}{c}\text { Developing different levels of BIM certification and } \\
\text { training programs }\end{array}$ & 3rd year & E\&T \\
\hline & & $\begin{array}{l}\text { BIM certification requirements for contract of works } \\
\text { in public sector }\end{array}$ & 2nd year & Procurement \\
\hline \multirow{7}{*}{$\begin{array}{l}\text { Not existing } \\
\text { BIM } \\
\text { standards } \\
\text { and } \\
\text { protocols }\end{array}$} & \multirow{3}{*}{$\begin{array}{l}\text { Incorporate } \\
\text { international } \\
\text { standards }\end{array}$} & $\begin{array}{c}\text { Enhance international collaboration to make use of } \\
\text { structured, validated, comparable datasets }\end{array}$ & 1st year & Leadership \\
\hline & & $\begin{array}{l}\text { Support replication of international and European } \\
\text { standards }\end{array}$ & 2nd year & Standards \\
\hline & & BIM training based on international standards & 2nd year & $\mathrm{E} \& \mathrm{~T}$ \\
\hline & \multirow{4}{*}{ Open BIM adoption } & $\begin{array}{l}\text { Consultation with key stakeholder groups for } \\
\text { commitment to adopting open, internationally } \\
\text { recognized information standards }\end{array}$ & 1st year & Leadership \\
\hline & & $\begin{array}{l}\text { "National Tools" based on open tools that help drive } \\
\text { general conformance with standards, avoid } \\
\text { duplication of effort, and avoid exclusion of SMEs }\end{array}$ & 4 th year & Standards \\
\hline & & BuildingSmart certification & 3rd year & E\&T \\
\hline & & $\begin{array}{l}\text { Ensure that public procedures (planning, mapping, } \\
\text { building inspections, public procurement) require } \\
\text { information in compliance with standards }\end{array}$ & 3rd year & Procurement \\
\hline \multirow{8}{*}{$\begin{array}{l}\text { Missing } \\
\text { culture for } \\
\text { collabora- } \\
\text { tive } \\
\text { projects }\end{array}$} & \multirow{4}{*}{$\begin{array}{l}\text { Removing } \\
\text { impediments }\end{array}$} & $\begin{array}{l}\text { Set up a central platform to act as digital resources } \\
\text { and tools bank to ease BIM introduction }\end{array}$ & 2nd year & Leadership \\
\hline & & Establishing national protocols for using BIM & 3rd year & Standards \\
\hline & & BIM guide workshops & 2nd year & E\&T \\
\hline & & $\begin{array}{l}\text { Support through online means the clients to receive, } \\
\text { review, manage, } \\
\text { and assess BIM on their projects }\end{array}$ & 3rd year & Procurement \\
\hline & \multirow{4}{*}{$\begin{array}{l}\text { Creating platform } \\
\text { for cross-sectional } \\
\text { collaboration }\end{array}$} & $\begin{array}{c}\text { Establishing knowledge hub for exchange of } \\
\text { experience }\end{array}$ & 1st year & Leadership \\
\hline & & $\begin{array}{l}\text { Links with international BIM platforms to ensure } \\
\text { standardization }\end{array}$ & 2nd year & Standards \\
\hline & & Advise on effective BIM implementation & 3rd year & E\&T \\
\hline & & BIM fund & 4th year & Procurement \\
\hline
\end{tabular}

Legend of fields of action: $\quad$ Leadership action; $\quad$ Standards; $\quad$ E\&T; $\quad$ Procurement. 


\section{References}

1. Barbosa, F.; Woetzel, J.; Srdhar, M.; Parsons, M.; Bertram, N.; Brown, S.; Mischke, J.; Ribeirinho, M. Reinventing Construction: A Route to Higher Productivity; McKinsey Global Institute: New York, NY, USA, 2017.

2. Alreshidi, E.; Mourshed, M.; Rezgui, Y. Requirements for cloud-based BIM governance solutions to facilitate team collaboration in construction projects. Requir. Eng. 2016, 23, 1-31. [CrossRef]

3. Doumbouya, L.; Gao, G.; Guan, C. Adoption of the Building Information Modeling (BIM) for construction project effectiveness: The review of BIM benefits. Am. J. Civ. Eng. Archit. 2016, 4, 74-79.

4. Powel, M.; Pancevski, I. Education and Employment Sector Linkages for the Building and Construction Sector, Bridging the Skills Gaps, UNDP Project. 2020. Available online: https://arhiva.skills4future.mk/en/development-of-stakeholdermapping-analysis-education-and-employment-sector-linkages-and-gaps-for-the-building-and-construction-sector (accessed on 5 February 2022).

5. Almeida, P.R.; Solas, M.Z.; Renz, A.; Bühler, M.M.; Gerbert, P.; Castagnino, S.; Rothballer, C. Shaping the Future of Construction: A Breakthrough in Mindset and Technology. Future of Construction; World Economic Forum: Geneva, Switzerland, 2016. [CrossRef]

6. World Economic Forum. Shaping the Future of Construction-An Action Plan to Accelerate Building Information Modeling (BIM) Adoption. 2018. Available online: https://www3.weforum.org/docs/WEF_Accelerating_BIM_Adoption_Action_Plan.pdf (accessed on 1 February 2022).

7. EU BIM Task Group. Handbook for the Introduction of Building Information Modeling by the European Public Sector; EU BIM Task Group, EC: Brussels, Belgium, 2017.

8. Luciani, C.; Garagnani, S.; Mingucci, R. BIM tools and design intent. Limitations and opportunities. In Practical BIM 2012-Management, Implementation, Coordination and Evaluation; Kensek, K., Peng, J., Eds.; University of Southern Carolina: Los Angeles, CA, USA, 2012.

9. Smart Market Report. The Business Value of BIM for Infrastructure, Dodge Data and Analytics. 2017. Available online: https://www2.deloitte.com/content/dam/Deloitte/us/Documents/finance/us-fas-bim-infrastructure.pdf (accessed on 1 February 2022).

10. Smart Market Report. The Business Value of BIM for Owners, McGraw-Hill Construction. 2014. Available online: https: //i2sl.org/elibrary/documents/Business_Value_of_BIM_for_Owners_SMR_(2014).pdf (accessed on 1 February 2022).

11. Ibrahim, H.S.; Hashim, N.; Jamal, K.A.A. The Potential Benefits of Building Information Modelling (BIM) in Construction Industry. IOP Conf. Ser. Earth Environ. Sci. 2019, 385, 012047. [CrossRef]

12. Eastman, C.M.; Eastman, C.; Teicholz, P.; Sacks, R. BIM Handbook: A Guide to Building Information Modeling for Owners, Managers, Designers, Engineers and Contractors; John Wiley and Sons: Hoboken, NJ, USA, 2011.

13. Patrick MacLeamy. The Future of the Building Industry (3/5): The Effort Curve, HOK. Available online: https://www.youtube. com/watch?v=9bUlBYc_Gl4\&ab_channel=HOKNetwork (accessed on 24 January 2022).

14. Smith, P. BIM Implementation-Global Strategies. Procedia Eng. 2014, 85, 482-492. [CrossRef]

15. Ullah, K.; Lill, I.; Witt, E. An Overview of BIM Adoption in the Construction Industry: Benefits and Barriers. In 10th Nordic Conference on Construction Economics and Organization; Emerald Reach Proceedings Series; Lill, I., Witt, E., Eds.; Emerald Publishing Limited: Bingley, UK, 2019; Volume 2, pp. 297-303.

16. Burgess, G.; Jones, M.; Muir, K. BIM in the UK House Building Industry: Opportunities and Barriers to Adoption; University of Cambridge: Cambridge, UK, 2018.

17. CitA. BIM Innovation Capability Programme (BICP), Global BIM Study: Lessons for Ireland's, BIM Programme. 2017. Available online: https:/ / arrow.tudublin.ie/cgi/viewcontent.cgi?article=1016\&context=beschrecrep (accessed on 24 January 2022).

18. McAuley, B.; Hore, A.; West, R. BICP Global BIM Study-Lessons for Ireland's BIM Programme; Construction IT Alliance (CitA) Limited: Dublin, Ireland, 2017.

19. NBC. Roadmap to Digital Transition for Ireland's Construction Industry 2018-2021. 2017. Available online: https://issuu.com/ constructionitalliance/docs/nbc_roadmap_to_digital_transition_updated_2020 (accessed on 19 November 2021).

20. Silva, M.J.F.; Salvado, F.; Couto, P.; Vale, A.Á. Roadmap Proposal for Implementing Building Information Modelling (BIM) in Portugal. Open J. Civ. Eng. 2016, 6, 475-481. [CrossRef]

21. Yang, J.B.; Chou, H.Y. Mixed approach to government BIM implementation policy: An empirical study of Taiwan. J. Build. Eng. 2018, 20, 337-343. [CrossRef]

22. Gerges, M.; Austin, S.; Mayouf, M.; Ahiakwo, O.; Jaeger, M.; Saad, A.; El Gohary, T. An investigation into the implementation of Building Information Modeling in the Middle East. Electron. J. Inf. Technol. Constr. 2017, 22, 1-15.

23. Succar, B.; Kassem, M. Macro-BIM adoption: Conceptual structures. Autom. Constr. 2015, 57, 64-79. [CrossRef]

24. Ghaffarianhoseini, A.; Tookey, J.; Ghaffarianhoseini, A.; Naismith, N.; Azhar, S.; Efimova, O.; Raahemifar, K. Building information modelling (BIM) uptake: Clear benefits, understanding its implementation, risks and challenges. Renew. Sustain. Energy Rev. 2017, 75, 1046-1053. [CrossRef]

25. Mtya, A.; Windapo, A. Drivers and barriers to the adoption of building information modelling (BIM) by construction firms in South Africa. Innov. Prod. Constr. 2019, 215-223. [CrossRef]

26. Senthilkumar, V. An exploratory study on the building information modeling adoption in United Arab Emirates municipal projects- current status and challenges. MATEC Web Conf. 2017, 120, 02015. [CrossRef] 
27. Ahmed, S. Barriers to Implementation of Building Information Modeling (BIM) to the Construction Industry: A Review. J. Civ. Eng. Constr. 2018, 7, 107. [CrossRef]

28. Hamma-Adama, M.; Kouider, T. Comparative Analysis of BIM Adoption Efforts by Developed Countries as Precedent for New Adopter Countries. Curr. J. Appl. Sci. Technol. 2019, 36, 1-15. [CrossRef]

29. Damali, Y.; Kamalesh, P.; Omar, N. Challenges Involved in Adopting BIM on the Construction Jobsite. EPiC Ser. Built Environ. 2021, 2, 302-310.

30. Bargstädt, H.J. Challenges of BIM for Construction Site Operations. Procedia Eng. 2015, 117, 52-59. [CrossRef]

31. Elagiry, M.; Marino, V.; Lasarte, N.; Elguezabal, P.; Messervey, T. BIM4Ren: Barriers to BIM Implementation in Renovation Processes in the Italian Market. Buildings 2019, 9, 200. [CrossRef]

32. Lee, G.; Borrmann, A. BIM policy and management. Constr. Manag. Econ. 2020, 38, 413-419. [CrossRef]

33. Stojanovska-Georgievska, L.; Spasevska, H.; Ivanov, R. Beyond the numbers-Result oriented report of the project TRAINEE. Zenodo 2020, 1, 11. [CrossRef]

34. Panchevski, I.; Ivanov, R.; Stamenkova, Z. Survey Report on Penetration and Acceptance of BIM Practice, D3.1. Project Deliverable of EU Project TRAINEE. 2018. Available online: http://trainee-mk.eu/images/TRAINEE/Deliverables/D3.1_Survey_about_ penetration_and_acceptance_of_BIM_practice_TRAINEE.pdf (accessed on 24 January 2022).

35. Stojanovska-Georgievska, L.; Sandeva, I.; Krleski, A.; Spasevska, H.; Ginovska, M.; Panchevski, I.; Ivanov, R.; Arnal, I.P.; Cerovsek, T.; Funtik, T. A Brief Report on the Actions towards the Introduction of BIM in the Macedonian Construction Sector. Environ. Sci. Proc. 2021, 11, 8. [CrossRef]

36. European Construction Sector Observatory. BIM in the EU Construction Sector. 2019. Available online: https:/ / ec.europa.eu/ growth/sectors/construction/observatory/trend-papers_en (accessed on 19 October 2021).

37. Zhong, Y. BIM-based Construction Training Program for Low-skilled Workforce: Visualization and Development of Equipment. Tools and Procedures for Construction Tasks. Master's Thesis, Bauhaus-Universität Weimar, Weimar, Germany, 2016.

38. Cerovsek, T. A review and outlook for a 'Building Information Model' (BIM): A multi-standpoint framework for technological development. Adv. Eng. Inform. 2011, 25, 224-244. [CrossRef]

39. BuildingSMART. Central Model Integration. 2016. Available online: BuildingSmart.org (accessed on 8 February 2022 ).

40. Daniotti, B.; Gianinetto, M.; Della Torre, S. Digital Transformation of the Design, Construction and Management Processes of the Built Environment; Springer: Berlin/Heidelberg, Germany, 2019.

41. BibLus BIM. BIM and Energy Certification: Here Is the BEM That Will Revolutionize the Work of Technicians. 2018. Available online: https:/ / bim.acca.it/bim-e-certificazione-energetica-bem (accessed on 8 February 2022).

42. International Awards Program. 2019. Available online: https://www.buildingsmart.org/awards/bsi-awards-2019 (accessed on 20 December 2021)

43. Carvalho, J.P.; Almeida, M.; Bragança, L.; Mateus, R. BIM-Based Energy Analysis and Sustainability Assessment-Application to Portuguese Buildings. Buildings 2021, 11, 246. [CrossRef]

44. Mateus, R.; Silva, S.M.; de Almeida, M.G. Environmental and cost life cycle analysis of the impact of using solar systems inenergy renovation of Southern European single-family buildings. Renew. Energy 2019, 137, 82-92. [CrossRef]

45. Stojanovska-Georgievska, L.; Ivanov, R.; Panchevski, I.; Perez Arnal, I. Proposal for National Roadmap for Introduction of BIM, D3.2. Project Deliverable of EU Project TRAINEE. 2020. Available online: http:/ / trainee-mk.eu/images/TRAINEE/Deliverables/ D32_ZBKK_Roadmap.pdf (accessed on 20 December 2021).

46. Chong, H.-Y.; Lee, C.-Y.; Wang, X. A mixed review of the adoption of Building Information Modelling (BIM) for sustainability. J. Clean. Prod. 2017, 142, 4114-4126. [CrossRef]

47. Carvalho, J.P.; Bragança, L.; Mateus, R. Sustainable building design: Analysing the feasibility of BIM platforms to support practical building sustainability assessment. Comput. Ind. 2021, 127, 103400. [CrossRef]

48. Reeves, T.; Olbina, S.; Issa, R.R.A. Guidelines for using building information modeling for energy analysis of buildings. Building 2015, 5, 1361-1388. [CrossRef]

49. Ardda, N.; Mateus, R.; Bragança, L. Methodology to Identify and Prioritise the Social Aspects to Be Considered in the Design of More Sustainable Residential Buildings-Application to a Developing Country. Buildings 2018, 8, 130. [CrossRef]

50. Li, X.; Wen, J. Review of building energy modeling for control and operation. Renew. Sustain. Energy Rev. 2014, 37, 517-537. [CrossRef]

51. Zhao, H.-X.; Magoulès, F. A review on the prediction of building energy consumption. Renew. Sustain. Energy Rev. 2012, 16, 3586-3592. [CrossRef]

52. Hong, T.; Chen, Y.; Luo, X.; Luo, N.; Lee, S.H. Ten questions on urban building energy modeling. Build. Environ. 2019, 168, 106508. [CrossRef]

53. Farzaneh, A.; Monfet, D.; Forgues, D. Review of using Building Information Modeling for building energy modeling during the design process. J. Build. Eng. 2019, 23, 127-135. [CrossRef] 